Review

\title{
Ni-Based Catalysts for Low Temperature Methane Steam Reforming: Recent Results on Ni-Au and Comparison with Other Bi-Metallic Systems
}

\author{
Hongjing Wu ${ }^{1,2}$, Valeria La Parola ${ }^{1}$, Giuseppe Pantaleo ${ }^{1}$, Fabrizio Puleo ${ }^{1,3}$, Anna M. Venezia ${ }^{1}$ \\ and Leonarda F. Liotta ${ }^{1, *}$
}

1 Institute for The Study of Nanostructured Materials (ISMN)-CNR, Via Ugo La Malfa 153, 90146 Palermo, Italy; E-Mails: wuhongjing@mail.nwpu.edu.cn (H.W.); valeria.laparola@cnr.it (V.P.); pantaleo@pa.ismn.cnr.it (G.P.); puleo@pa.ismn.cnr.it (F.P.); venezia@pa.ismn.cnr.it (A.M.V.)

2 Department of Applied Physics, Northwestern Polytechnical University (NPU), 127 Youyi Xilu, 710072 Xi'an, China

3 Department of Physics and Chemistry, University of Palermo, Viale delle Scienze Ed.17, 90128

Palermo, Italy

* Author to whom correspondence should be addressed; E-Mail: liotta@pa.ismn.cnr.it;

Tel.: +39-91-6809-371; Fax: +39-91-6809-399.

Received: 9 April 2013; in revised form: 22 May 2013 / Accepted: 30 May 2013 /

Published: 5 June 2013

\begin{abstract}
Steam reforming of light hydrocarbons provides a promising method for hydrogen production. Ni-based catalysts are so far the best and the most commonly used catalysts for steam reforming because of their acceptably high activity and significantly lower cost in comparison with alternative precious metal-based catalysts. However, nickel catalysts are susceptible to deactivation from the deposition of carbon, even when operating at steam-to-carbon ratios predicted to be thermodynamically outside of the carbon-forming regime. Reactivity and deactivation by carbon formation can be tuned by modifying Ni surfaces with a second metal, such as Au through alloy formation. In the present review, we summarize the very recent progress in the design, synthesis, and characterization of supported bimetallic Ni-based catalysts for steam reforming. The progress in the modification of $\mathrm{Ni}$ with noble metals (such as $\mathrm{Au}$ and $\mathrm{Ag}$ ) is discussed in terms of preparation, characterization and pretreatment methods. Moreover, the comparison with the effects of other metals (such as $\mathrm{Sn}, \mathrm{Cu}, \mathrm{Co}, \mathrm{Mo}, \mathrm{Fe}, \mathrm{Gd}$ and $\mathrm{B}$ ) is addressed. The differences of catalytic activity, thermal stability and carbon species
\end{abstract}


between bimetallic and monometallic Ni-based catalysts are also briefly shown.

Keywords: hydrocarbons steam reforming; nickel; gold; bimetallic; surface alloy; support modification

\section{Introduction}

Production of synthesis gas from natural gas and Fisher-Tropsch synthesis from the synthesis gas have become very important in the chemical industry for reasons related to the soaring petroleum price, depletion of oil reserves, and environmental problems with exhaust gases [1-3]. Steam reforming of methane and other hydrocarbons has been an extremely important process for the production of synthesis gas [4-6]. Steam reforming is the conventional method to produce synthesis gas from natural gas and is utilized on the industrial scale, which is highly endothermic reaction as indicated below (Equation (1)).

$$
\mathrm{CH}_{4}+\mathrm{H}_{2} \mathrm{O} \rightarrow \mathrm{CO}+3 \mathrm{H}_{2} \quad \Delta H^{0}{ }_{298 \mathrm{~K}}=+206 \mathrm{~kJ} \cdot \mathrm{mol}^{-1}
$$

In industry, hydrogen is practically produced from natural gas and mainly used for the ammonia synthesis [7-9]. Recently, much attention has been paid to the hydrogen production relating to the fuel cell technology [10-12]. Moreover, many efforts have been made in developing dry $\left(\mathrm{CO}_{2}\right)$ reforming of methane as a practical way to utilize $\mathrm{CO}_{2}$ as a building block in organic syntheses (Equation (2)) $[13,14]$.

$$
\mathrm{CH}_{4}+\mathrm{CO}_{2} \rightarrow 2 \mathrm{CO}+2 \mathrm{H}_{2} \quad \Delta H^{0}{ }_{298 \mathrm{~K}}=+286 \mathrm{~kJ} \cdot \mathrm{mol}^{-1}
$$

It has been pointed out that one problem in methane reforming is carbon deposition on the catalyst surface, which causes the catalyst deactivation. There are two principal carbon deposition pathways for steam reforming of methane: the methane decomposition (Equation (3)) and the CO disproportion (Equation (4)).

$$
\begin{array}{cl}
\mathrm{CH}_{4} \rightarrow \mathrm{C}+2 \mathrm{H}_{2} & \Delta H^{0}{ }_{298 \mathrm{~K}}=+75 \mathrm{~kJ} \cdot \mathrm{mol}^{-1} \\
2 \mathrm{CO} \rightarrow \mathrm{C}+\mathrm{CO}_{2} & \Delta H^{0}{ }_{298 \mathrm{~K}}=-172 \mathrm{~kJ} \cdot \mathrm{mol}^{-1} \\
\mathrm{CH}_{4}+2 \mathrm{O}_{2} \rightarrow \mathrm{CO}_{2}+2 \mathrm{H}_{2} \mathrm{O} & \Delta H^{0}{ }_{298 \mathrm{~K}}=-806 \mathrm{~kJ} \cdot \mathrm{mol}^{-1}
\end{array}
$$

The tendency to carbon deposition may depend on the atomic ratio $\mathrm{O} / \mathrm{C}$ and $\mathrm{H} / \mathrm{C}$ in the feed gas. Lower $\mathrm{H}_{2} \mathrm{O} / \mathrm{CH}_{4}$ and $\mathrm{H}_{2} / \mathrm{CO}$ ratios correspond to higher tendency toward coke formation [15]. This means that the tendency of carbon deposition in the dry reforming of methane is much higher than that in the steam reforming of methane. Coke formation is relatively severe over the catalysts used for $\mathrm{CO}_{2}$ reforming at high temperatures $(>1073 \mathrm{~K})$.

For steam and dry reforming of methane, the catalyst bed has to be heated from the outside of the reactor by the combustion of methane (Equation (5)). Therefore, the reaction rate is limited by the heat transfer and the scale merit of the syngas production by this method is low. Other combined technologies such as autothermal reforming, oxidative reforming, and so on, are used to realize the large-scale synthesis gas production. For example, oxidative steam reforming of methane, in which $\mathrm{O}_{2}$ 
is introduced to the catalyst bed together with methane and steam, is a promising method for syngas production because the reaction conditions can be adjusted by balancing exothermic combustion and endothermic reforming to an autothermal system.

Reforming of methane with steam and $\mathrm{CO}_{2}$ is catalyzed by various transition and noble metals such as $\mathrm{Ni}, \mathrm{Co}, \mathrm{Ru}, \mathrm{Rh}, \mathrm{Pd}, \mathrm{Pt}$, etc. The catalytic activity of metal catalysts supported on $\mathrm{Al}_{2} \mathrm{O}_{3}-\mathrm{MgO}$ was reported to follow the order: $\mathrm{Ru}>\mathrm{Rh}>\mathrm{Ir}>\mathrm{Ni}>\mathrm{Pt}$ [16]. Ni has a comparable activity to noble-metal catalysts, and that higher loading amount of $\mathrm{Ni}$ is feasible in terms of the catalyst cost in order to increase the activity per catalyst volume. Although $\mathrm{Ni}$ is inferior to noble metals regarding the resistance to carbon deposition and catalyst oxidation, the high resistance to coke formation and catalyst oxidation can be realized by the addition of very small amounts of noble metals. The modification of Ni catalysts with small amounts of noble metals such as $\mathrm{Pd}, \mathrm{Pt}, \mathrm{Ru}, \mathrm{Rh}$ and $\mathrm{Ir}$ has been well reviewed [1-3] and it has been demonstrated as a promising approach to design catalysts with excellent performances for methane reforming.

The present review article is related to the effects of modification of $\mathrm{Ni}$ catalysts by other metals (such as $\mathrm{Au}, \mathrm{Ag}, \mathrm{Sn}, \mathrm{Cu}, \mathrm{Co}, \mathrm{Mo}, \mathrm{Fe}, \mathrm{Gd}$ and B), with particular attention being devoted to bimetallic $\mathrm{Ni}-\mathrm{Au}$ catalysts. It is well known that the preparation method strongly influences the structure of bimetallic systems. The first part of this work is, therefore, devoted to the structural differences of catalysts prepared by different methods. In the second part, the resistance to coke formation in the steam reforming of methane, as well as the relationship between the catalytic performance and the structure of bimetallic catalysts, are discussed.

\section{Preparation and Structure of Ni Catalysts Modified with a Small Amount of Second Metals}

Table 1 lists the chemical composition of the main Ni-M catalysts $(\mathrm{M}=\mathrm{Au}, \mathrm{Ag}, \mathrm{Sn}, \mathrm{Cu}, \mathrm{Co}, \mathrm{Mo}$, $\mathrm{Fe}, \mathrm{Gd}$ and B) for hydrocarbon reforming [17-57] recently reported in the literature. Some typical examples are discussed in detail in the present review.

Table 1. List of $\mathrm{Ni}$ catalysts modified with a second metal reported in this review: chemical composition and catalytic reactions.

\begin{tabular}{ccccccc}
\hline Catalysts & $\begin{array}{c}\text { Second } \\
\text { metal }\end{array}$ & $\begin{array}{c}\text { Ni } \\
\text { content } \\
\text { (wt\%) }\end{array}$ & $\begin{array}{c}\text { Molar ratio } \\
\text { (M/Ni) }\end{array}$ & Reactions & $\begin{array}{c}\text { Second } \\
\text { metal } \\
\text { effects }\end{array}$ & Refs. \\
\hline $\mathrm{Au} / \mathrm{Ni} / \mathrm{MgAl}_{2} \mathrm{O}_{4}$ & $\mathrm{Au}$ & 16.5 & 0.0054 & SR of $n$-butane & $\mathrm{C}$ & {$[17-19]$} \\
$\mathrm{Au} / \mathrm{Ni} / \mathrm{MgAl}_{2} \mathrm{O}_{4}$ & $\mathrm{Au}$ & 8.8 & $0.0034-0.034$ & SR of methane & $\mathrm{C}$ & {$[20]$} \\
$\mathrm{Au} / \mathrm{Ni} / \mathrm{MgAl}_{2} \mathrm{O}_{4}$ & $\mathrm{Au}$ & 8 & 0.019 & SR of methane & $\mathrm{C}, \mathrm{A}$ & {$[21]$} \\
$\mathrm{Au}-\mathrm{Ni} / \mathrm{Al}_{2} \mathrm{O}_{3}$ & $\mathrm{Au}$ & 8 & 0.038 & SR of methane & $\mathrm{C}, \mathrm{A}$ & {$[22-24]$} \\
$\mathrm{Au}-\mathrm{Ni} / \mathrm{Al}_{2} \mathrm{O}_{3}$ & $\mathrm{Au}$ & 8 & 0.075 & PO of methane & $\mathrm{C}, \mathrm{A}$ & {$[25]$} \\
$\mathrm{Au}-\mathrm{Ni} / \mathrm{CrAl}_{3} \mathrm{O}_{6}$ & $\mathrm{Au}$ & 5 & $0.0060-0.12$ & PO of methane & $\mathrm{C}, \mathrm{A}$ & {$[26,27]$} \\
$\mathrm{Au}-\mathrm{Ni} / \mathrm{MgO}-\mathrm{Al}_{2} \mathrm{O}_{3}$ & $\mathrm{Au}$ & 5 & 0.12 & PO of methane & $\mathrm{C}$ & {$[28]$} \\
$\mathrm{AuNiAl} \mathrm{LDHs}(\mathrm{Cp})$ & $\mathrm{Au}$ & 79.5 & 0.011 & SR of methanol & - & {$[29]$} \\
$\mathrm{Au} / \mathrm{Ni} / \mathrm{GDC}(\mathrm{Dp})$ & $\mathrm{Au}$ & 65 & $0.01-0.04$ & SR of methane & $\mathrm{C}$ & {$[30]$} \\
$\mathrm{AuNi} / \mathrm{YSZ}(\mathrm{Cs})$ & $\mathrm{Au}$ & 50 & $0.01-0.05$ & SR of methane & $\mathrm{C}$ & {$[31]$} \\
$\mathrm{Ag}-\mathrm{Ni} / \mathrm{Al}_{2} \mathrm{O}_{3}$ & $\mathrm{Ag}$ & 8 & 0.038 & SR of methane & $\mathrm{C}$ & {$[22-24]$} \\
$\mathrm{Ag}-\mathrm{Ni} / \mathrm{Al}_{2} \mathrm{O}_{3}$ & $\mathrm{Ag}$ & 15 & $0.0036-0.022$ & SR of methane & $\mathrm{C}$ & {$[32]$} \\
\hline
\end{tabular}


Table 1. Cont.

\begin{tabular}{|c|c|c|c|c|c|c|}
\hline $\mathrm{Ag}-\mathrm{Ni} / \mathrm{Al}_{2} \mathrm{O}_{3}$ & $\mathrm{Ag}$ & 15 & 0.011 & SR of methane & $\mathrm{C}$ & [33] \\
\hline $\mathrm{AgNi} / \mathrm{YSZ}(\mathrm{Cs})$ & $\mathrm{Ag}$ & 50 & $0.01-0.05$ & SR of methane & $\mathrm{C}$ & [34] \\
\hline $\mathrm{Ag} / \mathrm{Ni} / \mathrm{MgAl}_{2} \mathrm{O}_{4}$ & $\mathrm{Ag}$ & 7.93 & 0.5 & SR of butane & $\mathrm{C}, \mathrm{S}$ & {$[35]$} \\
\hline $\mathrm{Ag} / \mathrm{Ni}$ alloy & $\mathrm{Ag}$ & - & - & SR & $\mathrm{C}$ & {$[36]$} \\
\hline $\mathrm{Sn}-\mathrm{Ni} / \mathrm{Al}_{2} \mathrm{O}_{3}$ & $\mathrm{Sn}$ & $7.0-71.8$ & $0.014-0.17$ & SR & $\mathrm{C}$ & [37] \\
\hline $\mathrm{Sn} / \mathrm{Ni} / \mathrm{Al}_{2} \mathrm{O}_{3}$ & $\mathrm{Sn}$ & 35 & 0.0049 & SR of methane & $\mathrm{C}$ & {$[38]$} \\
\hline $\mathrm{SnNi} / \mathrm{YSZ}(\mathrm{Cp})$ & $\mathrm{Sn}$ & 15 & 0.0049 & SR & $\mathrm{C}$ & [39-41] \\
\hline $\mathrm{Sn}-\mathrm{Ni} / \mathrm{MgO}-\mathrm{Al}_{2} \mathrm{O}_{3}$ & $\mathrm{Sn}$ & 11.25 & 0.16 & SR of methanol & $\mathrm{C}$ & {$[42]$} \\
\hline SnNi3 alloy & $\mathrm{Sn}$ & - & 0.33 & SR & $\mathrm{C}$ & [43] \\
\hline $\mathrm{Cu}-\mathrm{Ni} / \mathrm{Al}_{2} \mathrm{O}_{3}$ & $\mathrm{Cu}$ & 8.72 & 0.0092 & SR of methane & $\mathrm{A}, \mathrm{S}$ & [44] \\
\hline $\mathrm{Cu}-\mathrm{Ni} / \mathrm{Al}_{2} \mathrm{O}_{3}$ & $\mathrm{Cu}$ & $3-7$ & $0.40-2.16$ & SR of methanol & $\mathrm{S}, \mathrm{C}$ & {$[45]$} \\
\hline $\mathrm{Cu}-\mathrm{Ni} / \mathrm{Al}_{2} \mathrm{O}_{3}$ & $\mathrm{Cu}$ & 5 & 0.92 & SR of methane & $\mathrm{C}$ & {$[46]$} \\
\hline $\mathrm{Cu}-\mathrm{Ni} / \mathrm{SiO}_{2}$ & $\mathrm{Cu}$ & $1.25-3.75$ & $0.33-3$ & SR of ethanol & $\mathrm{A}, \mathrm{C}, \mathrm{S}$ & {$[47]$} \\
\hline $\mathrm{Cu}-\mathrm{Ni} / \mathrm{Al}_{2} \mathrm{O}_{3}$ & $\mathrm{Cu}$ & - & 1 & SR of methane & $\mathrm{C}$ & [48] \\
\hline $\mathrm{Cu}-\mathrm{Ni}-\mathrm{Mg}-\mathrm{Al}(\mathrm{Cp})$ & $\mathrm{Cu}$ & - & - & DR of methane & $\mathrm{C}$ & [49] \\
\hline $\mathrm{Cu} / \mathrm{Ni}(111)$ alloy & $\mathrm{Cu}$ & - & - & SR of methane & $\mathrm{C}$ & {$[50]$} \\
\hline Co-Ni-Mg-Al(Cp) & $\mathrm{Co}$ & - & 1.36 & DR of methane & $\mathrm{A}, \mathrm{C}$ & [49] \\
\hline Co-Ni/YSZ & $\mathrm{Co}$ & 25,34 & $0.44,0.92$ & SR of ethanol & S & {$[51]$} \\
\hline $\mathrm{Co}-\mathrm{Ni} / \mathrm{ZrO}_{2}$ & Co & $13,8.7$ & $1.00,0.500$ & DR of methane & $\mathrm{A}, \mathrm{C}, \mathrm{S}$ & [52] \\
\hline $\mathrm{MoO}_{3} / \mathrm{Ni} / \mathrm{Al}_{2} \mathrm{O}_{3}$ & Mo & - & - & SR of $n$-butane & $\mathrm{C}$ & [53] \\
\hline $\mathrm{MoO}_{3} / \mathrm{Ni} / \mathrm{Al}_{2} \mathrm{O}_{3}$ & Mo & 17 & $\begin{array}{c}0.00048- \\
0.048\end{array}$ & SR of $n$-butane & $\mathrm{A}, \mathrm{C}$ & [54] \\
\hline $\mathrm{Mo} / \mathrm{Ni} / \mathrm{Al}_{2} \mathrm{O}_{3}$ & Mo & 60 & $\begin{array}{c}0.00050- \\
0.0020\end{array}$ & SR of methane & A & [55] \\
\hline $\mathrm{Fe}-\mathrm{Ni}(\mathrm{Cp})$ & $\mathrm{Fe}$ & - & $0.33-1$ & SR of ethanol & $\mathrm{A}, \mathrm{C}$ & {$[56]$} \\
\hline $\mathrm{GdNi} / \mathrm{Al}_{2} \mathrm{O}_{3}(\mathrm{Cs})$ & $\mathrm{Gd}$ & 7 & 0.12 & PO,SR,DR & $\mathrm{C}$ & {$[57]$} \\
\hline $\mathrm{B} / \mathrm{Ni} / \mathrm{Al}_{2} \mathrm{O}_{3}$ & $\mathrm{~B}$ & 15 & $0.18,0.36$ & SR of methane & $\mathrm{C}$ & {$[58]$} \\
\hline
\end{tabular}

$\mathrm{M} / \mathrm{Ni}$, sequential impregnation; $\mathrm{M}-\mathrm{Ni}$, co-impregnation; $\mathrm{Cp}$, co-precipitation; $\mathrm{Dp}$, deposition-precipitation; Cs, combustion synthesis; SR, steam reforming; PO, partial oxidation; DR, dry reforming; ATR, autothermal reforming; A, activity; C, coke resistant; S, selectivity.

\subsection{Ni Metal Particles Modified with Au}

Nørskov and co-workers [17-19] have reported that $\mathrm{Au} / \mathrm{Ni}$ surface alloy on the $\mathrm{Ni}$ particles (on $\mathrm{SiO}_{2}$ and $\mathrm{MgAl}_{2} \mathrm{O}_{4}$ ) was active for steam reforming and more resistant towards carbon formation than the pure $\mathrm{Ni}$ catalysts. The $\mathrm{Ni} / \mathrm{SiO}_{2}$ and $\mathrm{Ni} / \mathrm{MgAl}_{2} \mathrm{O}_{4}$ with high surface area were prepared by precipitation-deposition and pore filling of the spinel support with Ni-nitrate, respectively. The bimetallic $\mathrm{Au} / \mathrm{Ni}$ catalysts were prepared by carefully impregnating the reduced monometallic $\mathrm{Ni}$ catalysts with an aqueous solution containing $\mathrm{Au}\left(\mathrm{NH}_{3}\right)_{4}\left(\mathrm{NO}_{3}\right)_{3}$. After filtering, the products were dried in air at $383 \mathrm{~K}$. They described in details how Monte Carlo simulations and various physicochemical characterization tools such as transmission electron microscopy (TEM), in situ extended X-ray absorption fine structure measurements (EXAFS), and X-ray powder diffraction (XRD) were used to get information on the existence of the $\mathrm{Au} / \mathrm{Ni}$ surface alloy in the small particle system encountered in the supported catalysts [18]. By fitting the back-transformed $\mathrm{Au} L_{3}$ spectrum of silica supported $\mathrm{Au} / \mathrm{Ni}$ 
catalyst, the nonzero value of the Au-Ni coordination number was observed and gave evidence for the presence of $\mathrm{Ni}$ in the nearest neighbor environment of Au. However, the Au-Au coordination number was larger than what could be expected for an Au surface alloy. Therefore, they took into account that XAFS probed all Au present in the catalyst; also Au presented as large Au particle as evidenced by TEM and XRD results. Linear combinations of calculated $\mathrm{Au} L_{3}$ XAFS functions of bulk $\mathrm{Au}$ and $\mathrm{Au} / \mathrm{Ni}$ surface alloys were compared to the experimental data by varying the amount of $\mathrm{Au}$ on $\mathrm{Ni}$ in the particles as well as the relative amount of bulk Au. The best fit results in $73 \%$ of the Au presented as bulk $\mathrm{Au}$ and the remainder of the $\mathrm{Au}$ presented as a surface alloy (molar ratio $\mathrm{Au} / \mathrm{Ni}=0.10$ ) on a $\mathrm{Ni}$ particle with a diameter of $1.8 \mathrm{~nm}$. No significant differences were observed between the EXAFS spectra and the Fourier transformed data of the freshly reduced catalyst and the catalyst after steam reforming in diluted $n$-butane.

King and co-workers [20] have reported that the addition of small quantities of gold to the surface of supported nickel catalysts has been proved to retard carbon formation during hydrocarbon steam reforming. After $\mathrm{Ni} / \mathrm{MgAl}_{2} \mathrm{O}_{4}$ being impregnated with $\mathrm{Au}$, the sample was dried in ambient air, heated in flowing $\mathrm{He}$ at a rate of $1 \mathrm{~K} / \mathrm{min}$ to $473 \mathrm{~K}$, than held isothermally at $473 \mathrm{~K}$ for at least $8 \mathrm{~h}$. Table 2 shows the results of fitting the back-transformed $\mathrm{Au} L_{3}$-edge data with both the $\mathrm{Au}-\mathrm{Ni}$ and $\mathrm{Au}$ - $\mathrm{Au}$ first coordination shells. Increasing $\mathrm{Au}$ loadings resulted in increased $\mathrm{Au}-\mathrm{Au}$ interaction and a parallel decrease in $\mathrm{Au}-\mathrm{Ni}$ interaction. For the $0.1 \mathrm{wt} \% \mathrm{Au} / 8.8 \mathrm{wt} \% \mathrm{Ni}$ sample, an average coordination number was 5.3, with a negligible coordination number of $\mathrm{Au}-\mathrm{Au}$ interaction. This means that at the lowest Au loading (0.1 wt\%), only Au-Ni bonds are detected. Furthermore, the XANES analysis of the $\mathrm{Au}-\mathrm{Ni} / \mathrm{MgAl}_{2} \mathrm{O}_{4}$ catalysts revealed changes in both the $\mathrm{Ni} K$-edge and $\mathrm{Au} L_{3}$-edge white line intensities, indicative of transfer of electronic charge from $\mathrm{Au}$ to $\mathrm{Ni}$ as a result of surface alloy formation.

Table 2. Structural parameters derived from fitting $\mathrm{Au} L_{3}$-edge EXAFS data for $\mathrm{Au}-8.8 \%$ $\mathrm{Ni} / \mathrm{MgAl}_{2} \mathrm{O}_{4}$ after reduction at $500{ }^{\circ} \mathrm{C}[20]$.

\begin{tabular}{ccccccccccc}
\hline $\begin{array}{c}\text { Au } \\
\text { concentration }\end{array}$ & \multicolumn{3}{c}{ Au $\boldsymbol{L}_{\mathbf{3}}$-edge fitting Au-Ni } & & \multicolumn{3}{c}{ Au $\boldsymbol{L}_{\mathbf{3}}$-edge fitting Au-Au } & \multicolumn{2}{c}{$\boldsymbol{R}$ factor } \\
\hline$(\%)$ & $C . N$. & $R(\AA)$ & $\Delta \sigma^{2} \times 10^{3}$ & $\Delta E_{0}$ & $C . N$. & $R(\AA)$ & $\Delta \sigma^{2} \times 10^{3}$ & $\Delta E_{0}$ & $(\%)$ \\
0.1 & $5.3 \pm 1.1$ & $2.58 \pm 0.01$ & $6.5 \pm 1.6$ & 0.2 & - & - & - & - & 4.7 \\
0.2 & $4.9 \pm 1.1$ & $2.59 \pm 0.02$ & $7.4 \pm 1.6$ & 4.2 & $4.0 \pm 1.3$ & $2.97 \pm 0.04$ & $8.3 \pm 4.3$ & 5.4 & 4.9 \\
0.4 & $3.7 \pm 0.7$ & $2.58 \pm 0.01$ & $5.5 \pm 0.1$ & 2.8 & $6.0 \pm 1.5$ & $2.82 \pm 0.01$ & $7.7 \pm 1.8$ & 4.9 & 2.1 \\
1.0 & $2.8 \pm 0.3$ & $2.57 \pm 0.01$ & $4.3 \pm 0.7$ & 4.1 & $7.6 \pm 1.0$ & $2.84 \pm 0.01$ & $6.5 \pm 0.6$ & 6.3 & 4.7 \\
\hline
\end{tabular}

Besides, the pretreatment also will influence the Au-Ni surface alloy formation. Table 3 shows a significant $\mathrm{Au}-\mathrm{Ni}$ nearest-neighbor interaction when the Ni component is in the reduced state, but there appears to be no interaction between $\mathrm{Au}$ and oxidized $\mathrm{Ni}$ atoms.

Recently, Lazar et al. [22-24] have synthesized the $1.0 \mathrm{wt} \% \mathrm{Au}-7.0 \mathrm{wt} \% \mathrm{Ni} / \gamma-\mathrm{Al}_{2} \mathrm{O}_{3}$ catalyst by co-impregnation method and found that the addition of $\mathrm{Au}$ improved the methane conversion, $\mathrm{CO}_{2}$ selectivity and $\mathrm{H}_{2}$ production at low temperatures $\left(T<600{ }^{\circ} \mathrm{C}\right)$. The impregnated catalysts were dried at room temperature overnight, calcined in $\mathrm{Ar}$ at $823 \mathrm{~K}$ and then, reduced in $\mathrm{H}_{2}$ at $823 \mathrm{~K}$. Taking all characterization results (XRD, $\mathrm{H}_{2}$ chemisorption and TEM) into account, they concluded that in the $\mathrm{Ni}-\mathrm{Au} / \gamma-\mathrm{Al}_{2} \mathrm{O}_{3}$ catalysts prepared by co-impregnation and reduced at $823 \mathrm{~K}$, no significant interaction of $\mathrm{Au}$ with $\mathrm{Ni}$ has been proved to appear and no formation of a superficial Au-Ni surface alloy was 
observed [24]. Maniecki et al. [25] have also prepared $2.0 \mathrm{wt} \% \mathrm{Au}-10.0 \mathrm{wt} \% \mathrm{Ni} / \mathrm{Al}_{2} \mathrm{O}_{3}$ catalysts by co-impregnation method and found that the addition of gold improved catalyst stability and activity in POM reaction. After drying they were calcined for $4 \mathrm{~h}$ in air at $673 \mathrm{~K}$. The temperature programmed in situ XRD patterns for NiO-Au mechanical mixture in $\left(5 \% \mathrm{H}_{2}+95 \% \mathrm{Ar}\right)$ gas mixture is presented in Figure 1a. It can be observed that the reduction of free $\mathrm{NiO}$ takes place above $473 \mathrm{~K}$ and at the temperature of $563 \mathrm{~K}$ only metallic $\mathrm{Ni}$ and $\mathrm{Au}$ phases are detectable. Further increase of temperature up to $1153 \mathrm{~K}$ leads to gradual shifts of $2 \theta$ values that characterize the Au-Ni alloy formation. Finally, at $1153 \mathrm{~K}$ only XRD lines assigned to Au-Ni alloy phase are visible. Figure 1b shows that Au-Ni alloy formation occurs in the mixture of $80 \mathrm{wt} \% \mathrm{NiO}-20 \mathrm{wt} \%$ Au after partial oxidation of methane at $1153 \mathrm{~K}$, after reduction in $\left(5 \% \mathrm{H}_{2}+95 \% \mathrm{Ar}\right)$ stream, at $1153 \mathrm{~K}$, and for $8 \mathrm{wt} \% \mathrm{Ni}-2 \mathrm{wt} \% \mathrm{Au} / \mathrm{Al}_{2} \mathrm{O}_{3}$ catalyst after partial methane oxidation (POM) reaction at $1153 \mathrm{~K}$. One can see that the Au-Ni alloy is formed in the reductive gas atmosphere and after reaction. The formation of $\mathrm{Au}-\mathrm{Ni}$ alloy during high temperature POM reaction is experimentally proved on $8 \mathrm{wt} \% \mathrm{Ni}-2 \mathrm{wt} \% \mathrm{Au} / \mathrm{Al}_{2} \mathrm{O}_{3}$ catalyst surface. The mechanism of the formation of the bimetallic particles mentioned above is described in Figure 2 on the basis of the above in situ XRD characterization results.

Table 3. Structural parameters derived from fitting $\mathrm{Au} L_{3}$-edge EXAFS data for $\mathrm{Au} / \mathrm{MgAl}_{2} \mathrm{O}_{4}$ following either oxidation or reduction, and for $\mathrm{Au} / \mathrm{Ni} / \mathrm{MgAl}_{2} \mathrm{O}_{4}$ after oxidation, all at $500{ }^{\circ} \mathrm{C}[20]$.

\begin{tabular}{ccccccc}
\hline Catalysts & Pretreatment & $\boldsymbol{C .} \boldsymbol{N .}$ & $\boldsymbol{R}(\AA)$ & $\boldsymbol{\Delta} \boldsymbol{\sigma}^{2} \times \mathbf{1 0}^{\mathbf{3}}$ & $\boldsymbol{\Delta} \boldsymbol{E}_{\mathbf{0}}$ & $\boldsymbol{R}$ factor $(\%)$ \\
\hline $0.2 \% \mathrm{Au} / \mathrm{MgO}-\mathrm{Al}_{2} \mathrm{O}_{3}$ & Reduced at $500{ }^{\circ} \mathrm{C}$ & $11.3 \pm 0.6$ & $2.86 \pm 0.002$ & $2.4 \pm 0.3$ & 5.62 & 0.4 \\
$0.2 \% \mathrm{Au} / \mathrm{MgO}-\mathrm{Al}_{2} \mathrm{O}_{3}$ & Oxidized at $500^{\circ} \mathrm{C}$ & $11.0 \pm 0.6$ & $2.86 \pm 0.002$ & $1.9 \pm 0.3$ & 5.62 & 0.4 \\
$0.2 \% \mathrm{Au}-8.8 \% \mathrm{Ni} / \mathrm{MgO}-\mathrm{Al}_{2} \mathrm{O}_{3}$ & Oxidized at $500^{\circ} \mathrm{C}$ & $11.9 \pm 0.9$ & $2.87 \pm 0.003$ & $2.0 \pm 0.4$ & 4.89 & 1.0 \\
\hline
\end{tabular}

Figure 1. XRD patterns for (a) nickel oxide (80\%)-gold $(20 \%)$ mechanical mixture reduced in situ in $\left(5 \% \mathrm{H}_{2}+95 \%\right.$ Ar) gas mixture at different temperatures, and (b) $(80 \%$ $\mathrm{NiO}-20 \% \mathrm{Au})$ mixture after partial oxidation of methane at $1153 \mathrm{~K}$, after reduction in $(5 \%$ $\mathrm{H}_{2}+95 \% \mathrm{Ar}$ ) at $1153 \mathrm{~K}$ and for $8 \% \mathrm{Ni}-2 \% \mathrm{Au} / \mathrm{Al}_{2} \mathrm{O}_{3}$ catalyst after reaction at $1153 \mathrm{~K} \mathrm{[25]}$.
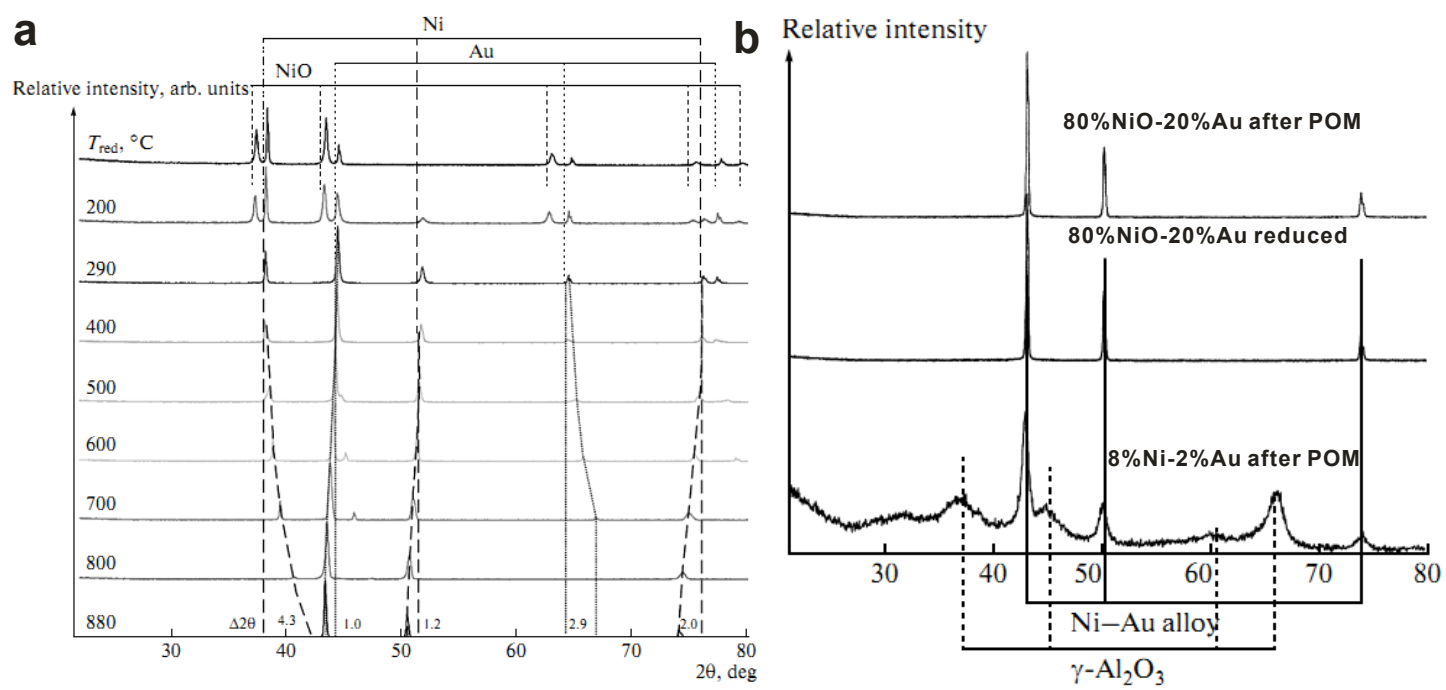
Figure 2. Model of the formation mechanism of Ni-Au bimetallic particles during the reduction pretreatment $\mathrm{Al}_{2} \mathrm{O}_{3}$ supported catalyst.

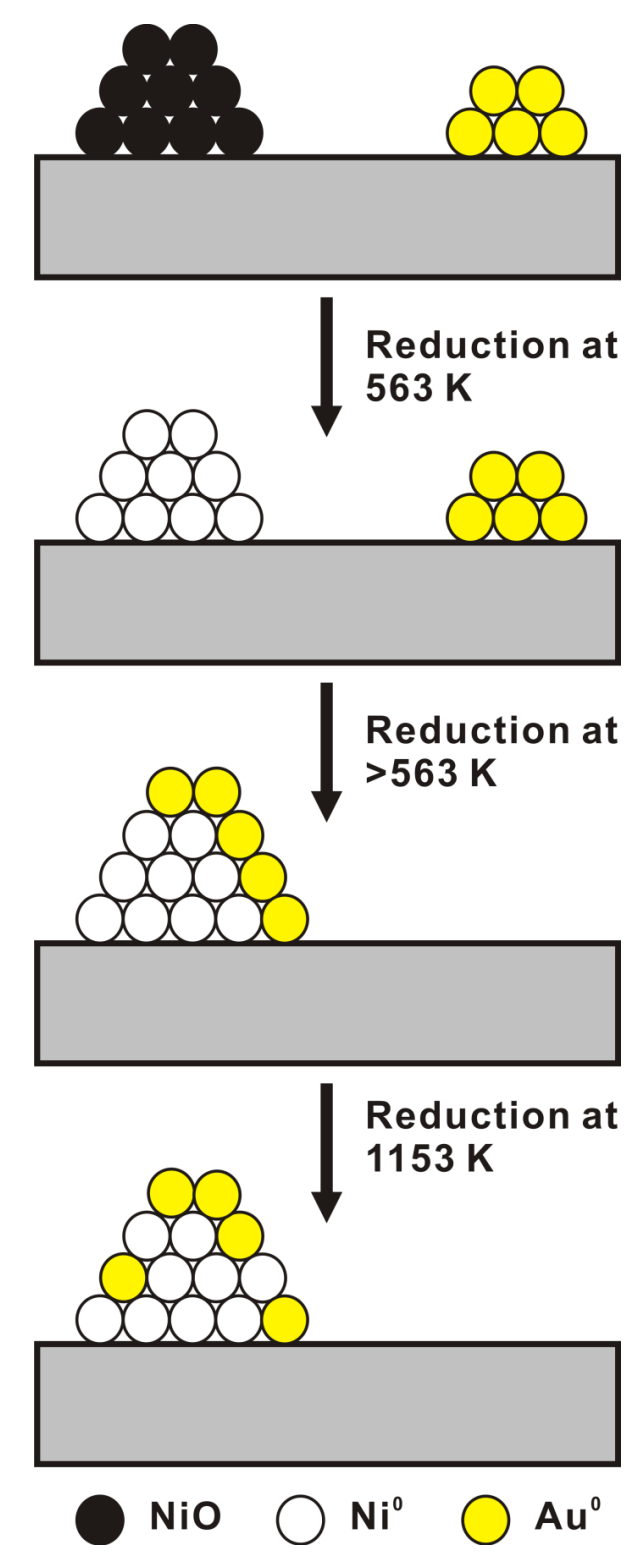

\subsection{Ni Metal Particles Modified with Ag}

Bueno and co-workers have prepared $\mathrm{Ni} / \gamma-\mathrm{Al}_{2} \mathrm{O}_{3}$ modified with $\mathrm{Ag}$ by co-impregnation method [32,33]. The impregnated samples were dried at $353 \mathrm{~K}$ overnight and calcined under flowing air at $723 \mathrm{~K}$ for $2 \mathrm{~h}$. Finally, the samples were reduced in $\mathrm{H}_{2}$ flow, heated at $10 \mathrm{~K} / \mathrm{min}$ and held at $1073 \mathrm{~K}$ for $2 \mathrm{~h}$. Figure 3 shows the in situ $\mathrm{Ni} K$-edge XANES-TPR- $\mathrm{H}_{2}$ spectra of the oxidized $5 \mathrm{wt} \% \mathrm{Ni} / \gamma-\mathrm{Al}_{2} \mathrm{O}_{3}$ and that doped by $0.6 \mathrm{wt} \% \mathrm{Ag}$ at different temperatures. The results indicate that two different species of $\mathrm{Ni}$ (II) are reduced in $\mathrm{AgNi} / \gamma-\mathrm{Al}_{2} \mathrm{O}_{3}$. There is no obviously shift in the threshold for reduced catalysts with higher Ag loading, with low contribution of Ag-Ni bonds relative to that of bulk Ni-Ni bonds. However, the presence of Ag changes the surface structure of the Ni sites that may be related to the nucleation and growth of graphitic structure. The catalysts with Ag loading $>0.3 \mathrm{wt} \%$ submitted to stability tests showed high resistance to coke deposition. 
Figure 3. In situ XANES spectra of $0.6 \mathrm{Ag} 5 \mathrm{NiAl}$ (A) and $5 \mathrm{NiAl}$ (B) samples under reduction conditions from 323 to $973 \mathrm{~K}$ [32].
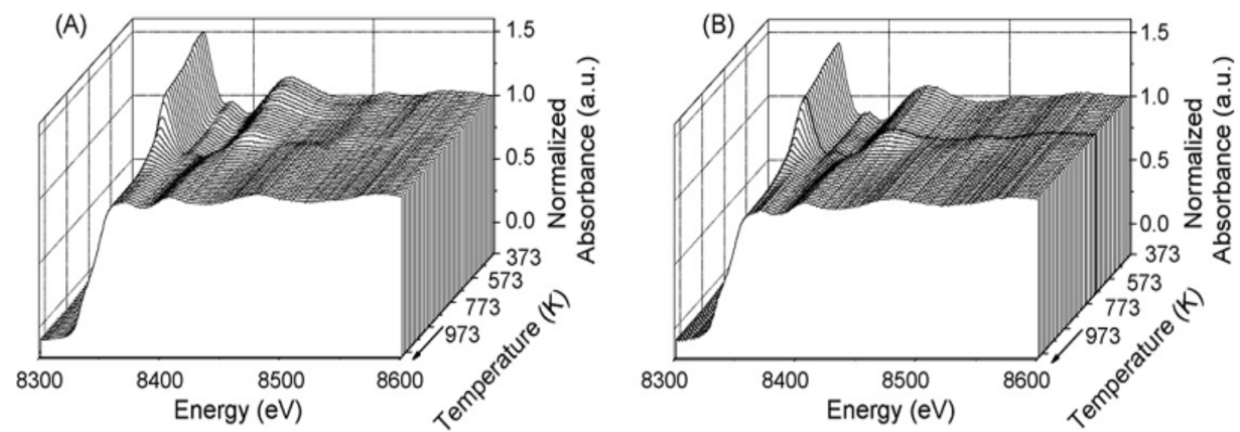

Recently, Kang et al. [35] have prepared $15 \mathrm{~mol} \% \mathrm{Ag} / 15 \mathrm{~mol} \% \mathrm{Ni} / \mathrm{MgAl}_{2} \mathrm{O}_{4}$ and $15 \mathrm{~mol} \% \mathrm{Ni} / 15$ mol\% $\mathrm{Ag} / \mathrm{MgAl}_{2} \mathrm{O}_{4}$ catalysts by the sequential wetness impregnation method. After being impregnated with $\mathrm{Ag}$ or $\mathrm{Ni}$, the sample was dried in ambient air, heated in flowing air at a rate of $10 \mathrm{~K} / \mathrm{min}$ to $773 \mathrm{~K}$, and then held isothermally at the final temperature for at least $1 \mathrm{~h}$. The reduction of the catalysts were performed in $\mathrm{H}_{2}$ at $973 \mathrm{~K}$ for $2 \mathrm{~h}$, followed by cooling to room temperature under Ar. Figure 4 shows the catalytic phase change and $n$-butane reforming mechanism. The catalytic performances differ according to the order in which the metal precursors are added. Ag is added between $\mathrm{Ni}$ and $\mathrm{Al}$ in an attempt to decrease the catalytic deactivation induced by the strong sintering between them during $n$-butane steam reforming, while simultaneously improving the catalytic activity. Consequently, their synergistic effect is different from that between $\mathrm{Au}$ and Ni nanoparticles as mentioned above. It gives a new interpretation about the effect of $\mathrm{Ag}$ in the bimetallic catalysts.

Figure 4. Expected phase transformation in the butane reforming before and after butane reforming reaction [35].

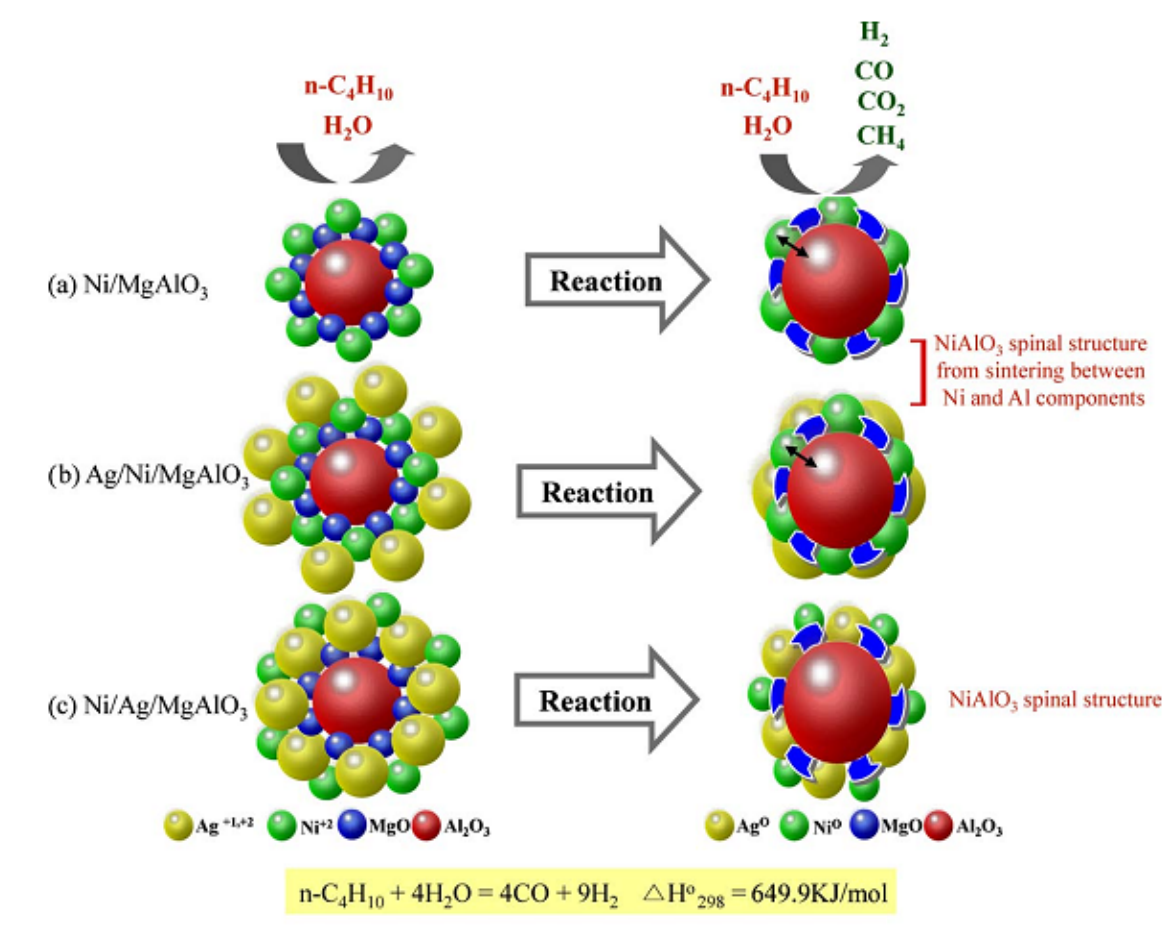

(A) Before reaction

(B) After reaction 
More recently, a density functional theory study of the effect $\mathrm{Ag}$ on the control of Ni-catalyzed carbon formation has been reported [36]. The calculated results indicated that the activation energy for methane dissociation was increased with the Ag coverage on Ni(211) surface than that on pure $\mathrm{Ni}(111)$, the active center was transferred from the stepped surface to the close-packed surface. The middle-step sites acted as the nucleation center for the growth of filamentous carbon and therefore had the potential to prevent catalyst nanoparticles from being destroyed. These findings provided a rational interpretation of the experimental observations that $\mathrm{Ag} / \mathrm{Ni}$ surface alloy exhibited lower catalytic activity towards steam reforming of methane but high resistance to coke formation.

\subsection{Ni Metal Particles Modified with Other Metals (Sn, Cu, Co, Mo, Fe, Gd and B)}

Linic and co-workers have extensively investigated $\mathrm{Ni}$ and $\mathrm{Sn}-\mathrm{Ni}$ alloy catalysts for hydrocarbons (methane, propane and isooctane) steam reforming [38-41]. By employing the Density Functional Theory (DFT), calculations on $\mathrm{Ni}$ and $\mathrm{Sn} / \mathrm{Ni}$ catalysts supported over $8 \mathrm{~mol} \%$ yttria-stabilized zirconia (YSZ) showed they identified Sn-Ni alloy as a potential carbon-tolerant reforming catalyst. Their DFT calculations showed that the formation energy of $\mathrm{Sn} / \mathrm{Ni}$ surface alloy was lower than the formation energy of Sn bulk alloys or than the formation energy corresponding to pure $\mathrm{Sn}$ and $\mathrm{Ni}$ phases, therefore, suggesting that the formation of $\mathrm{Sn} / \mathrm{Ni}$ surface alloy was thermodynamic favorable. It was deduced that $\mathrm{Sn}$ could displace $\mathrm{Ni}$ atoms from the step-edge sites, which effectively repelled $\mathrm{C}$ atoms from the low-coordinated step sites. This result indicated that $\mathrm{Sn}$ atoms lower the tendency of the surface alloy to form coke as confirmed in Figure 5b,c. Figure 5d shows the post-reaction STEM micrograph of $\mathrm{Ni}$ and $\mathrm{Sn} / \mathrm{Ni}$. Ni particles are completely covered with carbon deposits while $\mathrm{Sn} / \mathrm{Ni}$ is carbon-free. Furthermore, elemental mapping of $\mathrm{Sn} / \mathrm{Ni}$ particles via line scan (STEM/EDS) suggests surface alloying. Lower panel (Figure 5d) shows that $\mathrm{Sn} / \mathrm{Ni}$ ratio diminishes as the probe moves from the particle bottom edge upward, indicating the Sn surface enrichment.

It has been reported that the introduction of $\mathrm{Cu}$ in the catalyst formulation suppresses coke deposition and the sintering of the active phase, in steam/dry reforming of hydrocarbons [44-50]. Fornasiero et al. [45] have comprehensively studied the methanol and ethanol steam reforming activity of a series of $\mathrm{Ni}_{x} \mathrm{Cu}_{y} / \mathrm{Al}_{2} \mathrm{O}_{3}$ catalysts prepared by wet-impregnation method. Figure $6 \mathrm{a}$ shows a progressive shift of the metallic phase peaks. The XRD pattern shows diffraction peaks in an intermediate position, indicating the formation of a $\mathrm{Ni}-\mathrm{Cu}$ surface alloy. The composition and the number of alloys depend on the $\mathrm{Ni}: \mathrm{Cu}$ ratio. Figure $6 \mathrm{~b}$ shows the comparison between the experimental cell parameter $a$ of the metallic phases and the theoretical value calculated by Vegard's law for intermediate composition. The cell parameter of $\mathrm{Ni}_{3} \mathrm{Cu}_{7}$ and $\mathrm{Ni}_{5} \mathrm{Cu}_{5}$ is appreciably different with respect to the theoretical values. When the $\mathrm{Ni}: \mathrm{Cu}$ ratio decreases the lattice parameter increases. There may be two metal phases: a $\mathrm{Cu}$ rich alloy and a Ni-rich alloy, existed in the $\mathrm{Ni}_{3} \mathrm{Cu}_{7}$. Whereas, only one cubic structure alloy is detectable for the metal phase in the $\mathrm{Ni}_{5} \mathrm{Cu}_{5}$. The discrepancy between the observed and theoretical cell parameters suggests that, also in this case, two metal phase alloys could be present. 
Figure 5. (a) normalized conversion; (b) Ni 2p XPS spectra after isooctane reforming on $\mathrm{Ni}$ (red) and on $\mathrm{Sn} / \mathrm{Ni}$ (blue); (c) XRD spectra for post-isooctane $\mathrm{Ni}$ and $\mathrm{Sn} / \mathrm{Ni}$, and for fresh $\mathrm{Ni}$ catalysts, and (d) post-reaction STEM micrograph of $\mathrm{Ni}$ and $\mathrm{Sn} / \mathrm{Ni}$ [38].
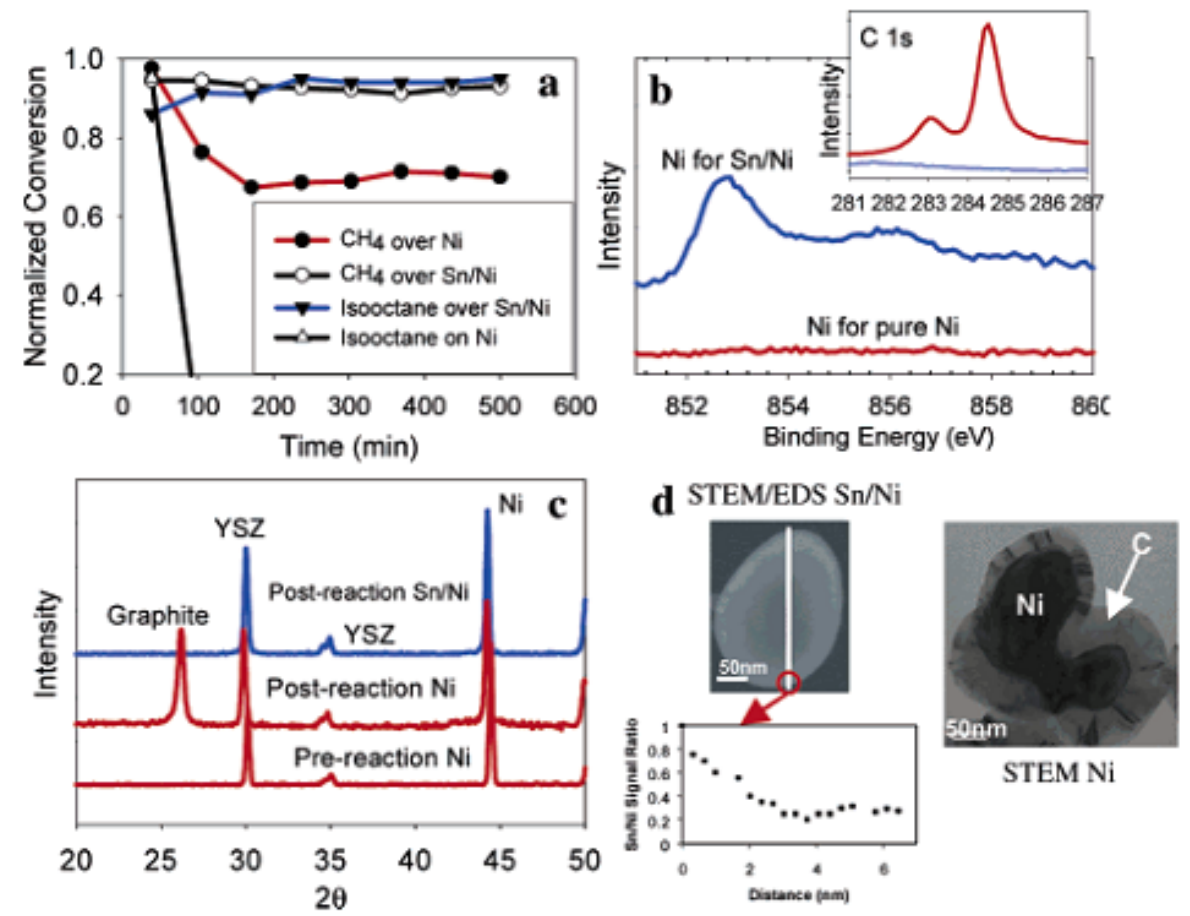

Figure 6. (A) Detail of the range $2 \theta=70-80^{\circ}$ of the XRD patterns of the reduced $\mathrm{Cu}, \mathrm{Ni}$ and $\mathrm{Ni}_{x} \mathrm{Cu}_{1-x}$ samples, shows the shift of the (220) reflection with the composition, and (B) trend of the experimental cell parameter $a$ with the composition of the metal phase, in comparison with the theoretical values [45].
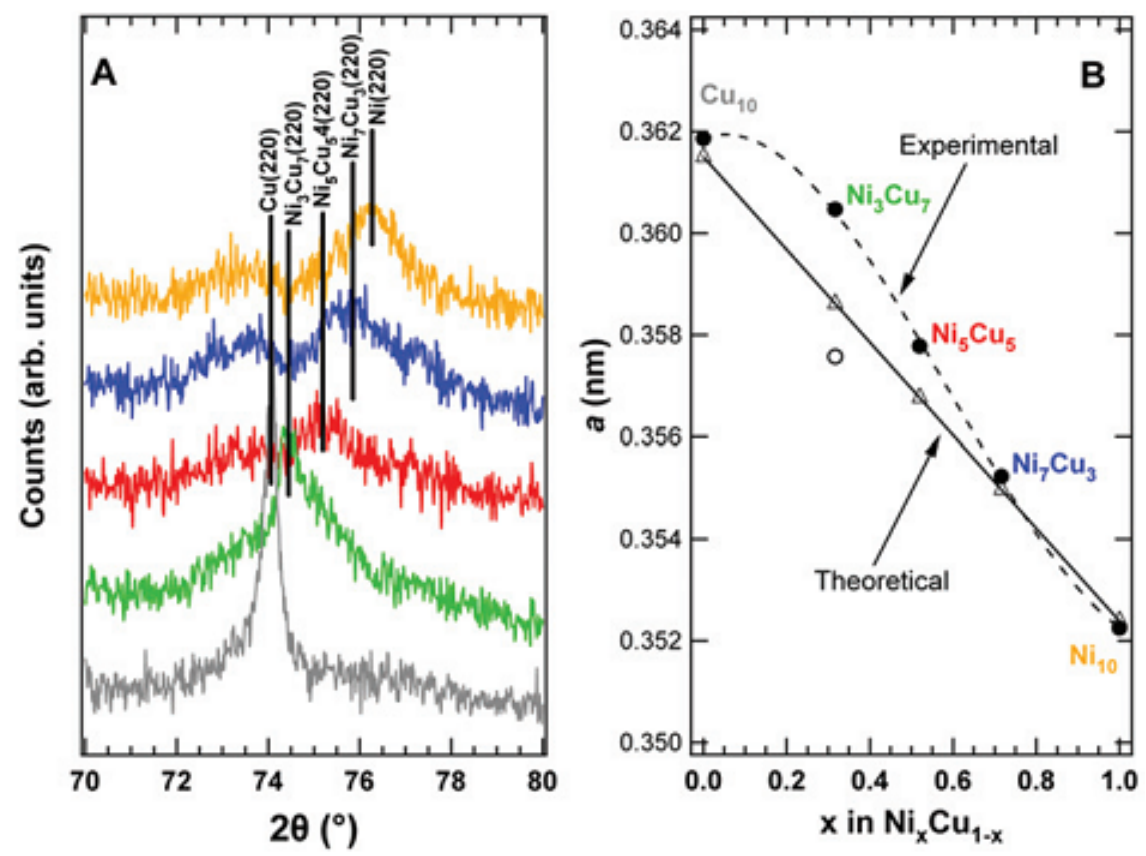
The effect of the addition of Co on Ni-based systems was also studied [51,52]. Ni-Co catalysts with different composition $\left.\mathrm{Ni}_{(1-x}\right) \mathrm{Co}_{x}(x=0,0.32,0.5)$ were prepared on yttria-stabilised zirconia (YSZ) as catalysts for ethanol steam reforming. TEM micrographs of the catalysts, $50 \mathrm{wt} \% \mathrm{Ni} / \mathrm{YSZ}$ and $\mathrm{Ni}(25 \mathrm{wt} \%)-\mathrm{Co}(25 \mathrm{wt} \%) / \mathrm{YSZ}$ (labeled as $\mathrm{Ni}_{25} \mathrm{Co}_{25} / \mathrm{YSZ}$ ) are shown in Figure $7 \mathrm{a}-\mathrm{c}$, respectively. The materials are composed of a powder which is heterogeneous in size. As detected by EDS analysis, $50 \mathrm{wt} \% \mathrm{Ni} / \mathrm{YSZ}$ is composed by relatively large Ni clusters (whose crystal size is tens of nm) deposited over small particles of YSZ support, better shown in Figure $7 \mathrm{~b}$ (crystal size $=5 \mathrm{~nm}$ ). The TEM micrograph of $\mathrm{Ni}_{25} \mathrm{Co}_{25} / \mathrm{YSZ}$ catalyst is shown in Figure 7c. Isolated crystals of Ni-Co alloy, with particle size of 50-100 nm, were detected along with smaller particles mainly constituted by the YSZ support. XRD analysis of the Ni-Co catalysts confirmed the alloy formation, showing a progressive increase of the lattice parameter from $3.524 \AA$ (for pure $\mathrm{Ni}$ ) up to $3.529 \AA$ determined for $\mathrm{Ni}_{1-x} \mathrm{Co}_{x}$ alloys in agreement with Vegard's law (Figure 7d). Moreover, Gonzalez-delaCruz et al. [52] reported that bimetallic Co-Ni catalysts showed a better activity and stability than the nickel monometallic system. They proposed the formation in the bimetallic systems of a more reducible nickel-cobalt alloy phase, which remains completely metallic in contact with the $\mathrm{CO}_{2} / \mathrm{CH}_{4}$ reactants at any temperature. The strong synergic effect between $\mathrm{Ni}$ and Co sites accounts for the better performance of the bimetallic catalysts.

Figure 7. TEM micrographs of fresh catalysts: (a and b) $50 \mathrm{wt} \% \mathrm{Ni} / \mathrm{YSZ}$ sample; (c) $\mathrm{Ni}(25 \mathrm{wt} \%)-\mathrm{Co}(25 \mathrm{wt} \%) / Y S Z$ sample; (d) lattice parameter $a(\AA)$ vs. $X_{\mathrm{Co}}$, Co loading, for Ni-Co alloys [51].
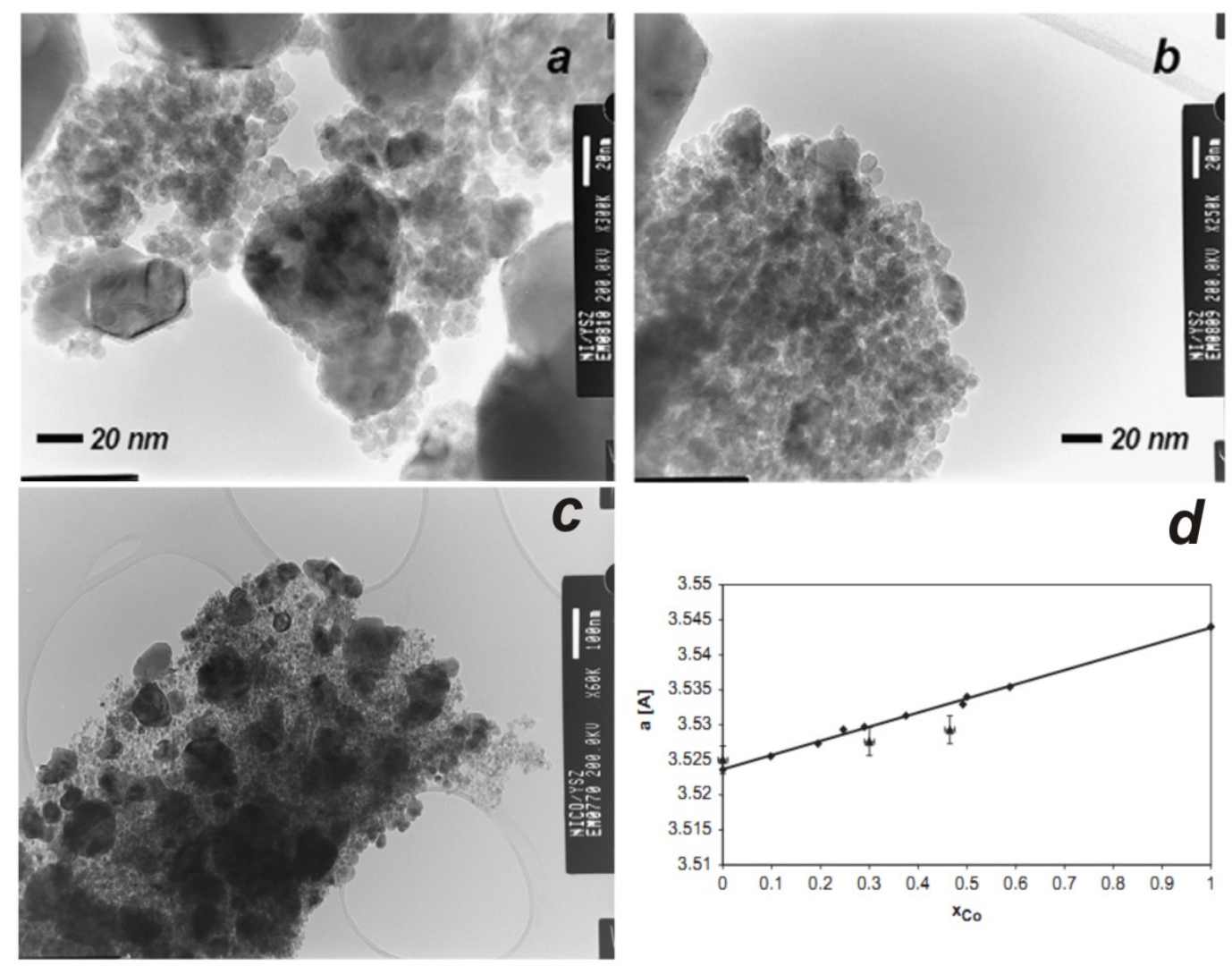
The promoting effect of small amounts of molybdenum oxide $(0.1 \mathrm{wt} \%)$ on the resistance to coking of $\mathrm{Ni} / \mathrm{Al}_{2} \mathrm{O}_{3}$ catalysts for methane and $n$-butane steam reforming were investigated by Borowiecki and Golebiowski $[53,54]$. The properties of Ni-Mo catalysts depend on the hydrogen-steam ratio in the reaction mixture which affects the mean degree of oxidation states of $\mathrm{MoO}_{x}$. The addition of Mo to $\mathrm{Ni} / \mathrm{Al}_{2} \mathrm{O}_{3}$ catalysts for methane steam reforming was recently investigated also by Maluf and Assaf [55], who found evidence of the transfer of electrons form $\mathrm{MoO}_{x}$ species to $\mathrm{Ni}$, leading to an increase in the electron density of metallic $\mathrm{Ni}$, and hence, the catalytic activity.

Interestingly, for the first time, a variety of $\mathrm{Ni}-\mathrm{Fe}$ mixed oxides derived from $\mathrm{Ni}$-Fe hydrotalcite has been reported by Abelló et al., for ethanol steam reforming [56]. They observed a positive role of iron in nickel-based catalysts in terms of enhanced catalytic activity, improved dispersion of nickel and lower carbon deposition.

The effects of lanthanide promoters $\left(\mathrm{La}_{2} \mathrm{O}_{3}, \mathrm{CeO}_{2}, \mathrm{Pr}_{2} \mathrm{O}_{3}, \mathrm{Sm}_{2} \mathrm{O}_{3}\right.$ and $\left.\mathrm{Gd}_{2} \mathrm{O}_{3}\right)$ on a Ni/ $\mathrm{Al}_{2} \mathrm{O}_{3}$ catalyst for methane partial oxidation, steam and $\mathrm{CO}_{2}$ reforming were recently addressed by Shao and co-workers [57]. Raman spectroscopy indicated that the addition of lanthanide promoters can reduce the degree of graphitization of carbon deposited over nickel. Moreover, $\mathrm{O}_{2}$-TPO results evidenced that among the investigated systems, $\mathrm{GdNi}-\mathrm{Al}_{2} \mathrm{O}_{3}$ posses the best coke resistance.

Figure 8. B $1 \mathrm{~s}$ XPS spectra for calcined and reduced $15 \mathrm{wt} \% \mathrm{Ni} / \gamma-\mathrm{Al}_{2} \mathrm{O}_{3}$ catalysts with various $\mathrm{B}$ contents [58].
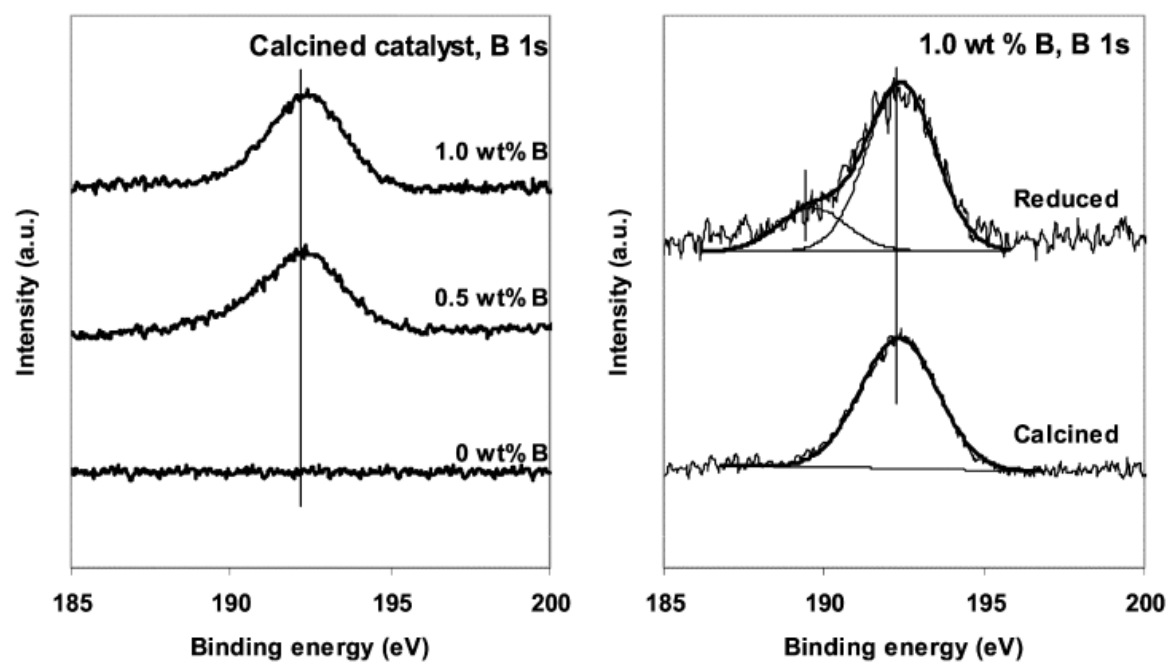

Based on first principle calculations, Saeys and Borgna [58] proposed that a small amount of boron could possibly enhance the stability of Ni catalysts. Since B and C exhibit similar chemisorptions preferences on Ni catalysts, a small amount of B might selectively block the most stable binding sites. Blocking most active sites first by $\mathrm{B}$, therefore, potentially reduces coke deposition. Supported Ni catalysts were prepared by aqueous slurry impregnation with a nickel nitrate solution to produce $\mathrm{Ni}$ content of $15 \mathrm{wt} \%$ on a commercial $\gamma-\mathrm{Al}_{2} \mathrm{O}_{3}$ support (BET area: $380 \mathrm{~m}^{2} / \mathrm{g}$ ). After drying at $353 \mathrm{~K}$ overnight and calcination at $673 \mathrm{~K}$ for $2 \mathrm{~h}$, boric acid was sequentially introduced following the same preparation procedure to produce B content of 0.5 or $1.0 \mathrm{wt} \%$. The XPS spectra (Figure 8) suggest that only $\mathrm{B}$ atoms interacting with $\mathrm{Ni}$ particles can be reduced, while a significant amount of boron oxide, probably interacting with the $\gamma-\mathrm{Al}_{2} \mathrm{O}_{3}$ support, cannot be reduced. Because $\gamma-\mathrm{Al}_{2} \mathrm{O}_{3}$ without $\mathrm{Ni}$ 
impregnated with $1 \mathrm{wt} \% \mathrm{~B}$ and subjected to the reduction procedure, no shift in the B 1s XPS peak could be found (not shown). The characterization studies indicate that boron might adsorb on both the $\mathrm{Ni}$ particles and the $\gamma-\mathrm{Al}_{2} \mathrm{O}_{3}$ support, and that $1 \mathrm{wt} \% \mathrm{~B}$ is sufficient to block the step and subsurface sites.

\section{Catalytic Activity of Ni-Au Catalysts and Comparison with Other Ni-Based Bimetallic Systems}

Among the above mentioned bimetallic Ni-M systems, some examples have been selected for comments on catalytic activity.

Nørskov and co-workers have proved that Au-Ni surface alloy catalyst is a less reactive but more robust steam reforming catalyst than pure $\mathrm{Ni}$ catalyst by experimental tests and theoretical calculations by using $\mathrm{CH}_{4}$ and $n$-butane as probe molecules [17-19]. The Au/Ni catalyst hardly deactivates, whereas the pure $\mathrm{Ni}$ catalyst rapidly forms carbon and deactivates. Thus, the $\mathrm{Au} / \mathrm{Ni}$ catalyst exhibiting the surface alloy is more resistant towards carbon formation than the pure Ni catalyst. King and co-workers then have comprehensively studied the loss of activity as a result of Au promotion, as well as the effect of $\mathrm{Au}$ addition on methane steam reforming under typical conditions of industrial reformer operation [20]. They found that carbon formation was not totally suppressed, and with increasing temperature, the effect of $\mathrm{Au}$ addition decreased. Addition of $0.4 \mathrm{wt} \%$ Au to $8.8 \mathrm{wt} \%$ $\mathrm{Ni} / \mathrm{MgAl}_{2} \mathrm{O}_{4}$ showed a small decrease in catalyst activity and a small increase in catalyst stability for methane steam reforming at $823 \mathrm{~K}$. However, Guczi and co-workers [21] have recently reported that the addition of $0.5 \mathrm{wt} \% \mathrm{Au}$ to $\mathrm{NiMgAl}_{2} \mathrm{O}_{4}$, although retards the methane dry reforming activity measured in temperature programmed reaction (Figure 9), the activity of the bimetallic Ni-Au system is improved during long time runs. In Figure 10 the concentration and conversion of $\mathrm{CO}, \mathrm{CO}_{2}$ and $\mathrm{CH}_{4}$ during overnight reaction at $948 \mathrm{~K}$ are displayed for $\mathrm{Ni} / \mathrm{MgAl}_{2} \mathrm{O}_{4}$ and $\mathrm{NiAu} / \mathrm{MgAl}_{2} \mathrm{O}_{4}$ catalysts, respectively. Moreover, on the Au containing bimetallic catalyst the formation of carbon nanotubes was retarded or vanished, in the experimental conditions investigated.

Figure 9. Comparison of $\mathrm{Ni} / \mathrm{MgAl}_{2} \mathrm{O}_{4}$ and $\mathrm{NiAu} / \mathrm{MgAl}_{2} \mathrm{O}_{4}$ catalysts in $\mathrm{CO}_{2}+\mathrm{CH}_{4}$ in first reaction ( $\boldsymbol{}^{\boldsymbol{\sigma}}$ and $\boldsymbol{\nabla}$, respectively) and after TPO $\left(\boldsymbol{\nabla}^{\mathrm{and}} \boldsymbol{\boldsymbol { \Delta }}\right.$, respectively) [21].

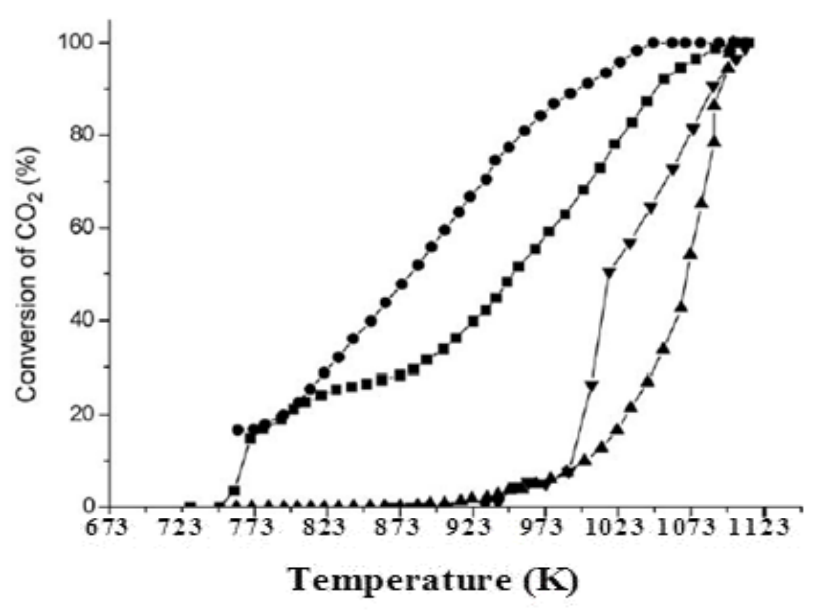




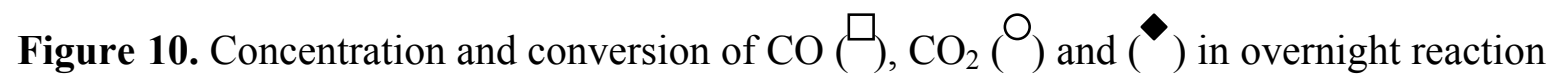
at $948 \mathrm{~K}$ : (a) on $\mathrm{Ni} / \mathrm{MgAl}_{2} \mathrm{O}_{4} ;(\mathbf{b})$ on $\mathrm{NiAu} / \mathrm{MgAl}_{2} \mathrm{O}_{4}[21]$.
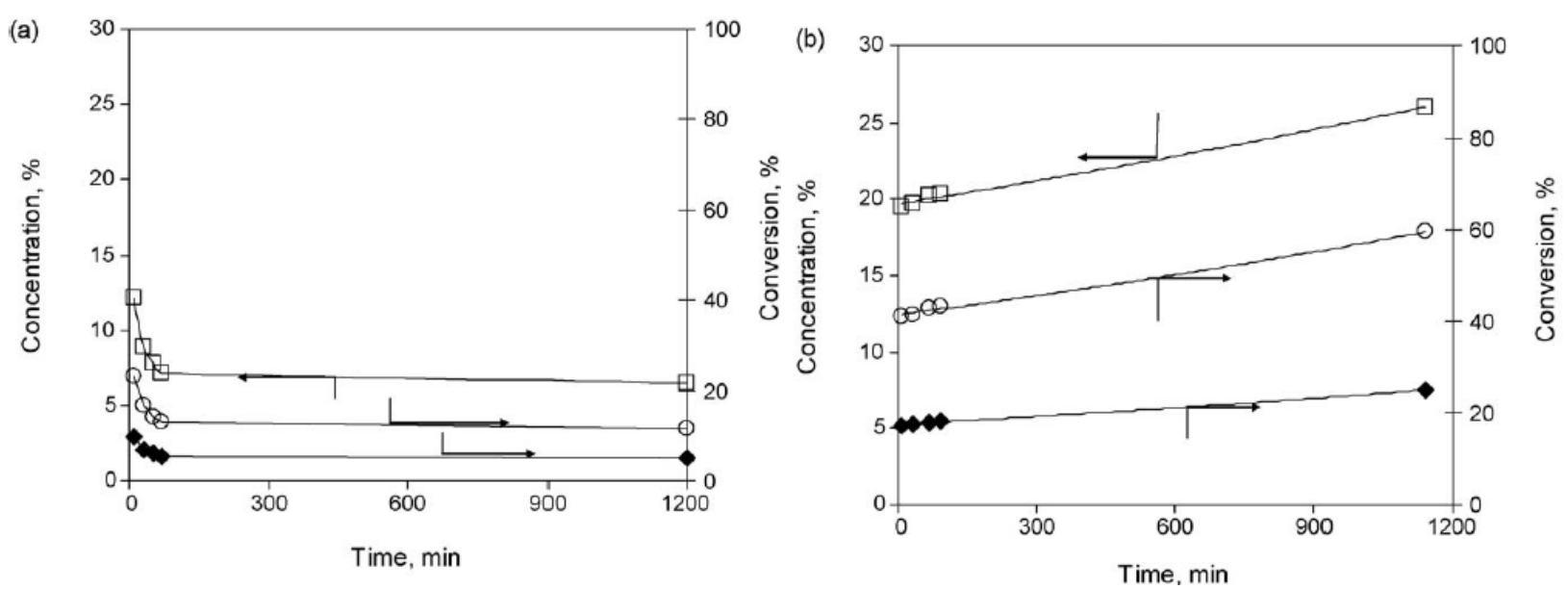

Furthermore, Lazar et al. [22-24] have found that the addition of $\mathrm{Au}$ to the nickel catalyst improved the methane conversion, $\mathrm{CO}_{2}$ selectivity and hydrogen production at low reaction temperatures $(T<873 \mathrm{~K})$. At $973 \mathrm{~K}$ under their working conditions, the additives had no important effect in hydrogen production by methane steam reforming, and the catalysts deactivated. Therefore, the result is very consistent with the report by King et al [20]. On the other hand, Maniecki et al. have reported that the addition of $\mathrm{Au}$ to $\mathrm{Ni} / \mathrm{Al}_{2} \mathrm{O}_{3}$ system improved catalyst stability and activity in partial oxidation of methane to synthesis gas [25,26-28]. Based on the results above mentioned, it can be found that there is discrepancy between results reported by different authors with respect to the effect of the addition of gold on catalytic activity of Ni-based catalysts. However, it seems to be confirmed that the addition of gold could improve the resistance of the Ni catalysts towards deactivation due to coke deposition.

Lazar et al. [22-24] have reported that the addition of Ag decreased the catalytic properties of $\mathrm{Ni}$ catalyst. The catalysts with Ag loading of 0.3 or $0.6 \mathrm{wt} \%$ submitted to stability tests showed high resistance to coke deposition reported by Bueno et al. [32]. They further found that at more oxidant conditions (autothermal reforming of methane, ATRM and POM) the redox process led to NiO formation and catalyst deactivation by $\mathrm{NiAl}_{2} \mathrm{O}_{4}$ formation [33]. At higher temperatures most probably due to Ag evaporation from Ag doped Ni/YSZ surface, severe anode catalytic and electro-catalytic activity degradation was observed by Neophytides et al. [34]. However, the addition of $\mathrm{Ag}$ could reduce the degree of carbon deposition and improve the $\mathrm{H}_{2}$ product selectivity by eliminating the formation of $\mathrm{C}_{2}$ hydrocarbons at temperature less than $1023 \mathrm{~K}$ in the butane steam reforming [35].

Catalytic steam reforming of methane and isooctane over pure $\mathrm{Ni}$ and 1\% $\mathrm{Sn}$ : Ni catalysts are also shown in Figure 5a. The steam to carbon ratios are 0.5 and 1.5 for methane and isooctane, respectively. At $1073 \mathrm{~K}$, the monometallic Ni catalyst rapidly deactivates. Unlike $\mathrm{Ni}$, the $\mathrm{Sn}-\mathrm{Ni}$ catalyst is active and stable for as long as it is kept on stream, approximately $12 \mathrm{~h} \mathrm{[38].}$

Nikolla et al. have shown that $\mathrm{Sn} / \mathrm{Ni}$ alloy deposited over YSZ is much more carbon-tolerant than monometallic $\mathrm{Ni}$ in the steam reforming of methane, propane and isooctane at moderate steam to carbon ratios [39]. Figure 11 shows the normalized conversion of methane over the $1 \mathrm{wt} \%$ and $5 \mathrm{wt} \%$ $\mathrm{Sn} / \mathrm{Ni} / \mathrm{YSZ}$ and $\mathrm{Ni} / \mathrm{YSZ}$ catalysts at a steam-to-carbon ratio of 0.5 and operating temperature of 
$1073 \mathrm{~K}$. It is evident that $\mathrm{Ni} / \mathrm{YSZ}$ lost about $45 \%$ of its activity after $2 \mathrm{~h}$ of reaction, whereas the $1 \mathrm{wt} \%$ $\mathrm{Sn} / \mathrm{Ni} / \mathrm{YSZ}$ was stable for the entire long-run time $(15 \mathrm{~h})$. By increasing the $\mathrm{Sn}$ loading from 1 to $5 \mathrm{wt} \%$, methane conversion was reduced by $\sim 25 \%$, suggesting a negative effect on $\mathrm{C}-\mathrm{H}$ bond activation.

The introduction of $\mathrm{Cu}$ in the $\mathrm{Ni}$ catalysts was also investigated for methanol and ethanol steam reforming [45]. The addition of $\mathrm{Cu}$ showed a positive effect inhibiting the formation of methane, an undesirable by-product. Although in the ethanol steam reforming the promoter effect of $\mathrm{Cu}$ was less promising, enhanced stability was observed in the two experiments, indicating a positive role was played by the $\mathrm{Cu}-\mathrm{Ni}$ bimetallic catalysts.

Figure 11. Normalized methane conversion (methane conversion divided by the highest obtained conversion) as a function of the time on stream for $1 \mathrm{wt} \% \mathrm{Sn} / \mathrm{Ni} / \mathrm{YSZ}, 5 \mathrm{wt} \%$ $\mathrm{Sn} / \mathrm{Ni} / \mathrm{YSZ}$ and Ni/YSZ catalysts measured at the steam-to carbon ratio of 0.5 and $1073 \mathrm{~K}$ [39].

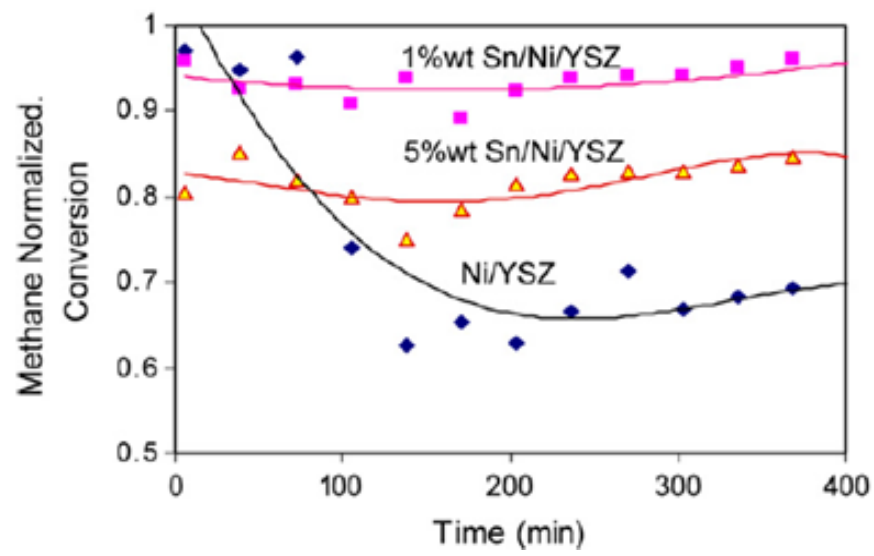

The effect of the addition of Co on the catalytic activity of Ni/YSZ catalyst for the ethanol steam reforming reaction was also studied by Resini et al. [51]. The addition of Co resulted in the inhibition of the dehydration reaction, as well as of methane production. Furthermore, Co also had an effect on the hydrogen production by increasing it, and thus, apparently favoring methane steam reforming.

Borowiecki et al. have reported that small amounts of $\mathrm{MoO}_{3}$ (up to $0.1 \mathrm{wt} \%$ ) caused an increase in activity of doped Ni catalysts [54]. By further increasing the amount of promoter (about $0.5 \mathrm{wt} \%$ ), a drop occurs (Figure 12a). The catalytic properties of Ni-Mo catalysts depend also on the $\mathrm{H}_{2}$ vol\% concentration in the reaction stream. Figure $12 \mathrm{~b}$ shows the dependence of the methane steam reforming rate on the hydrogen concentration at $873 \mathrm{~K}$ for $\mathrm{Ni}$ and different Ni-Mo catalysts. The activity of monometallic Ni gradually decreased by increasing hydrogen, while for Ni-Mo catalysts activity maxima were observed as a function of hydrogen content.

Shao and coworkers have, recently, compared the catalytic properties of lanthanide promoters $\mathrm{Ni}-\mathrm{Al}_{2} \mathrm{O}_{3}$ catalysts, highlighting for $\mathrm{GdNi}-\mathrm{Al}_{2} \mathrm{O}_{3}$ the best coke resistance and the good stability for methane partial oxidation at $1123 \mathrm{~K}$ for $300 \mathrm{~h}$ (Figure 13) [57]. 
Figure 12. (a) Dependence of catalysts activity in steam reforming of methane at different temperatures as a function of the promoter amount $\left({ }^{\bigcirc} 873 \mathrm{~K},{ }^{\square} 823 \mathrm{~K},{ }^{\triangle} 773 \mathrm{~K}\right)$; (b) Influence of hydrogen on the activity of catalysts in steam reforming of methane $\left({ }^{\mathrm{Ni}} \mathrm{Ni}\right.$, $\square_{\text {Ni-Mo (0.5), }}^{\Delta}$ Ni-Mo (1.0), ${ }^{\diamond}$ Ni-Mo (2.0)) [54].
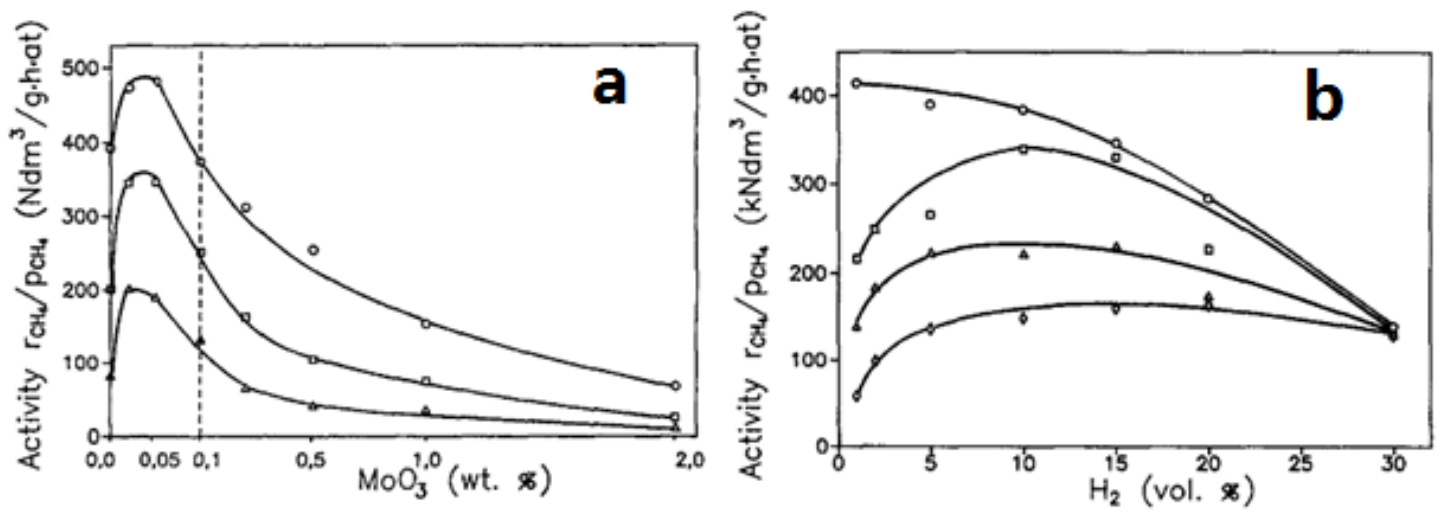

Figure 13. Time dependence of methane conversion and $\mathrm{H}_{2}$ to $\mathrm{CO}$ ratio under $\mathrm{CH}_{4}: \mathrm{O}_{2}=2: 1$ conditions at $850{ }^{\circ} \mathrm{C}$ for $\mathrm{GdNi}-\mathrm{Al}_{2} \mathrm{O}_{3}$ catalyst [57].

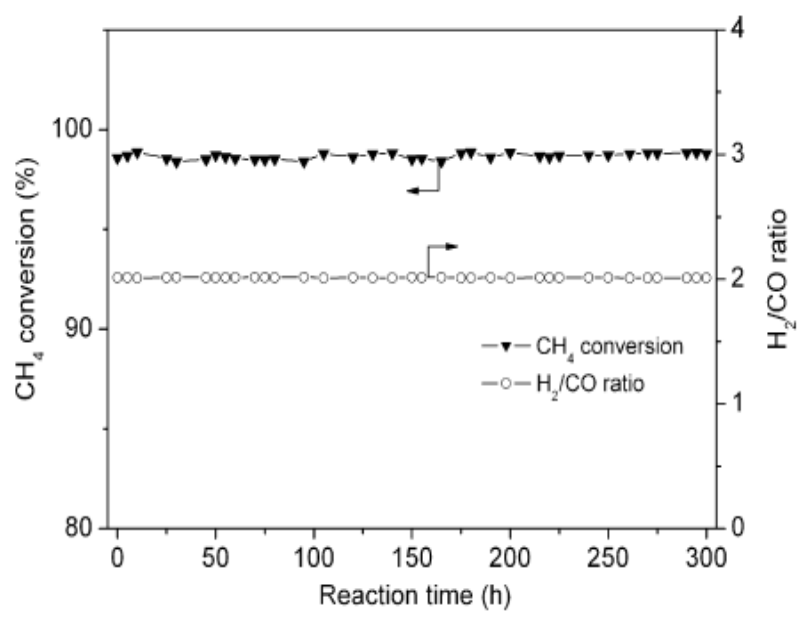

Interestingly, Borgna and Saeys [58] found that a small amount of boron could enhance the stability without compromising the catalytic activity. Catalytic tests showed that promotion with $1.0 \mathrm{wt} \%$ boron reduced the rate of deactivation by a factor of 3 and increased the initial methane conversion from $56 \%$ to $61 \%$.

\section{Conclusions}

The addition of a small amount of second metals such as $\mathrm{Au}, \mathrm{Ag}, \mathrm{Sn}, \mathrm{Cu}, \mathrm{Co}$, et al. to $\mathrm{Ni}$ catalysts significantly modifies the properties of metallic Ni particles by the formation of Ni-M bimetallic surface alloys. The structure of bimetallic surface alloys could be changed by choosing different preparation methods or pretreatments.

In particular, the addition of a small amount of $\mathrm{Au}$ to $\mathrm{MgAl}_{2} \mathrm{O}_{4}$-supported $\mathrm{Ni}$ catalysts by the sequential impregnation method leads to the formation of $\mathrm{Au}$ atoms, which segregated on the surface of the bimetallic particles when the Au loading is high, while well-mixed Au-Ni surface alloys are 
formed when the $\mathrm{Au}$ loading is low $(0.1 \mathrm{wt} \%)$. The co-impregnation method results in different structures of Au-Ni bimetallic catalysts according to the different authors' reports. Some authors reported that $\mathrm{Au}-\mathrm{Ni}$ surface alloys could be also formed on the $\mathrm{Ni} / \mathrm{Al}_{2} \mathrm{O}_{3}$ catalysts prepared by co-impregnation method. While, some other authors found that no formation of a superficial Au-Ni surface alloy was observed.

Compared to monometallic $\mathrm{Ni}$ catalysts, Ni-M bimetallic catalysts exhibit superior catalytic performance in the methane steam reforming, i.e., high activity, high resistance to carbon formation and sintering of metal particles, and high selectivity to $\mathrm{H}_{2}$ product. The improved catalytic performance of Ni catalysts modified with a small amount of second metals has been attributed to the synergic effect between a second metal and $\mathrm{Ni}$ by the formation of a superficial bimetallic alloy (such as $\mathrm{Ni}-\mathrm{Au}, \mathrm{Ni}-\mathrm{Ag}, \mathrm{Ni}-\mathrm{Sn}, \mathrm{Ni}-\mathrm{Cu}, \mathrm{Ni}-\mathrm{Co}$, etc.).

As a result, we expect that the following mentioned studies would lead to a further progress in the development of coke resistant bimetallic Ni-based catalysts for steam/dry reforming of methane:

- The DFT studies of Ni containing bi/trimetallic alloys or Ni catalysts modified with a second inorganic element would lead to design and preparation of novel Ni-based catalysts;

- The comprehensive understanding of the formation mechanisms of bimetallic surface alloys and their effects on catalytic performance and carbon formation would lead to design and preparation of new Ni-based catalysts with improved activity, stability and selectivity;

- We feel that the development of novel Ni catalysts modified with a second inorganic element (such as Mo, Fe, Gd and B) should deserve further research studies for steam/dry reforming of methane;

- The design of Ni catalysts with selected crystal planes of Ni and Ni-M alloyed particles could find applications in steam/dry reforming of methane.

\section{Acknowledgments}

The authors acknowledge the financial support provided by EFOR-CNR Project (Energies by Renewable sources). The China Scholarship Council is sincerely acknowledged for supporting Wu's scholarship. Hongjing $\mathrm{Wu}$ thanks the Excellent Doctorate Foundation, Doctorate Foundation of Northwestern Polytechnical University, and the Scholarship Award for Excellent Doctoral Student granted by Ministry of Education.

\section{References}

1. Tomishige, K. Oxidative steam reforming of methane over Ni catalysts modified with noble metals. J. Jpn. Pet. Inst. 2007, 50, 287-298.

2. Liu, C.J.; Ye, J.Y.; Jiang, J.J.; Pan, Y.X. Progresses in the preparation of coke resistant Ni-based catalyst for steam and $\mathrm{CO}_{2}$ reforming of methane. Chemcatchem 2011, 3, 529-541.

3. Li, D.L.; Nakagawa, Y.; Tomishige, K. Methane reforming to synthesis gas over Ni catalysts modified with noble metals. Appl. Catal. A 2011, 408, 1-24.

4. Trimm, D.L. Coke formation and minimisation during steam reforming reactions. Catal. Today 1997, 37, 233-238. 
5. Rafiqul, L.; Weber, C.; Lehmann, B.; Voss, A. Energy efficiency improvements in ammonia production-presperctives and uncertainties. Energy 2005, 30, 2487-2504.

6. Rostrup-Nielsen, J.; Trimm, D.L. Mechanisms of carbon formation on nickel-containing catalysts. J. Catal. 1977, 48, 155-165.

7. Pená, M.A.; Gómez, J.P.; Fierro, J.L.G. New catalytic routes for syngas and hydrogen production. Appl. Catal. A 1996, 144, 7-57.

8. Armor, J.N. The multiple roles for catalysis in the production of $\mathrm{H}_{2}$. Appl. Catal. A 1999, 176, 159-176.

9. Rostrup-Nielsen, J.R.; Rostrup-Nielsen, T. Large-scale hydrogen production. Cattech 2002, 6, 150-159.

10. Silva, L.C.; Murata, V.V.; Hori, C.E.; Assis, A.J. Hydrogen production from methane steam reforming: Parametric and gradient based optimization of a Pd-based membrane reactor. Optim. Eng. 2010, 11, 441-458.

11. Roh, H.S.; Jung, Y.; Koo, K.Y.; Jung, U.H.; Seo, Y.S.; Yoon, W.L. $\mathrm{H}_{2}$ production over $\mathrm{Ni} / \gamma-\mathrm{Al}_{2} \mathrm{O}_{3}$ catalyst prepared by a homogeneous precipitation method using urea for direct internal reforming (DIR) in a molten carbonate fuel cell (MCFC). Chem. Lett. 2009, 38, 1162-1163.

12. Rameshan, C.; Stadlmayr, W.; Weilach, C.; Penner, S.; Lorenz, H.; Havecker, M.; Blume, R.; Rocha, T.; Teschner, D.; Knop-Gericke, A.; et al. Subsurface-controlled $\mathrm{CO}_{2}$ selectivity of PdZn near-surface alloys in $\mathrm{H}_{2}$ generation by methanol steam reforming. Angew. Chem. Int. Ed. 2010, 49, 3224-3227.

13. Centi, G.; Perathoner, S. Opportunities and prospects in the chemical recycling of carbon dioxide to fuels. Catal. Today 2009, 148, 191-205.

14. Schaefer, M.; Behrendt, F.; Hammer, T. Evaluation of strategies for the subsequent use of $\mathrm{CO}_{2}$. Front. Chem. Eng. China 2010, 4, 172-183.

15. Edwards, J.H.; Maitra, A.M. The chemistry of methane reforming with carbon dioxide and its current and potential applications. Fuel Process. Technol. 1995, 42, 269-289.

16. Rostrup-Nielsen, J.R.; Hansen, J.H.B. $\mathrm{CO}_{2}$-reforming of methane over transition metals. J. Catal. 1993, 144, 38-49.

17. Besenbacher, F.; Chorkendorff, I.; Clausen, B.S.; Hammer, B.; Molenbroek, A.M.; Nørskov, J.K.; Stensgaard, I. Design of a surface alloy catalyst for steam reforming. Science 1998, 279, 1913-1915.

18. Molenbroek, A.M.; Nørskov, J.K.; Clausen, B.S. Structure and reactivity of Ni-Au nanoparticles catalysts. J. Phys. Chem. B 2001, 105, 5450-5458.

19. Holmblad, P.M.; Larsen, J.H.; Chorkendorff, I.; Nielsen, L.P.; Besenbacher, F.; Stensgaard, I.; Lægsgaard, E.; Kratzer, P.; Hammer, B.; Nørskov, J.K. Designing surface alloys with specific active sites. Catal. Lett. 1996, 40, 131-135.

20. Chin, Y.H.; King, D.L.; Roh, H.S.; Wang, Y.; Heald, S.M. Structure and reactivity investigations on supported bimetallic Au-Ni catalysts used for hydrocarbon steam reforming. J. Catal. 2006, 244, 153-162.

21. Guczi, L.; Stefler, G.; Geszti, O.; Sajó, I.; Pászti, Z.; Tompos, A.; Schay, Z. Methane dry reforming with $\mathrm{CO}_{2}$ : A study on surface carbon species. Appl. Catal. A 2010, 375, 236-246. 
22. Lazar, M.D.; Dan, M.; Mihet, M.; Almasan, V.; Rednic, V.; Borodi, G. Hydrogen production by low temperature methane steam reforming using $\mathrm{Ag}$ and $\mathrm{Au}$ modified alumina supported nickel catalysts. Rev. Roum. Chim. 2011, 56, 637-642.

23. Lazar, M.D.; Mihet, M.; Dan, M.; Almasan, V.; Marginean, P. Preparation and characterization of nickel based multicomponent catalysts. J. Phys. Conf. Ser. 2009, 182, doi:10.1088/1742-6596/ 182/1/012049.

24. Dan, M.; Mihet, M.; Biris, A.R.; Marginean, P.; Almasan, V.; Borodi, G.; Watanabe, F.; Biris, A.S.; Lazar, M.D. Supported nickel catalysts for low temperature methane steam reforming: comparison between metal additives and support modification. React. Kinet. Mech. Catal. 2012, 105, 173-193.

25. Maniecki, T.P.; Stadnicheno, A.I.; Maniukiewicz, W.; Bawolak, K.; Mierczynski, P.; Boronin, A.I.; Jozwiak, W.K. An active phase transformation on surface of $\mathrm{Ni}-\mathrm{Au} / \mathrm{Al}_{2} \mathrm{O}_{3}$ catalyst during partial oxidation of methane to synthesis gas. Kinet. Catal. 2010, 51, 573-578.

26. Maniecki, T.P.; Bawolak, K.; Gebauer, D.; Mierczynski, P.; Jozwiak, W.K. Catalytic activity and physicochemical properties of $\mathrm{Ni}-\mathrm{Au} / \mathrm{Al}_{3} \mathrm{CrO}_{6}$ system for partial oxidation of methane to synthesis gas. Kinet. Catal. 2009, 50, 138-144.

27. Maniecki, T.P.; Bawolak, K.; Mierczynski, P.; Jozwiak, W.K. Development of stable and highly active bimetallic $\mathrm{Ni}$-Au catalysts supported on binary oxides $\mathrm{CrAl}_{3} \mathrm{O}_{6}$ for POM reaction. Catal. Lett. 2009, 128, 401-404.

28. Maniecki, T.P.; Bawolak-Olczak, K.; Mierczynski, P.; Maniukiewicz, W.; Jozwiak, W.K. Effect of the chemical composition of $(\mathrm{MgO})_{x}\left(\mathrm{Al}_{2} \mathrm{O}_{3}\right)_{y}$ support on the catalytic performance of $\mathrm{Ni}$ and Ni-Au catalysts for the partial oxidation of methane. Chem. Eng. J. 2009, 154, 142-148.

29. Qi, C.X.; Amphlett, J.C.; Peppley, B.A. Methanol steam reforming over NiAl and Ni (M) Al layered double hydroxides ( $\mathrm{M}=\mathrm{Au}, \mathrm{Rh}, \mathrm{Ir})$ derived catalysts. Catal. Lett. 2005, 104, 57-62.

30. Niakolas, D.K.; Ouweltjes, J.P.; Rietveld, G.; Dracopoulos, V.; Neophytides, S.G. Au-doped $\mathrm{Ni} / \mathrm{GDC}$ as a new anode for SOFCs operating under rich $\mathrm{CH}_{4}$ internal steam reforming. Int. J. Hydrogen Energy 2010, 35, 7898-7904.

31. Gavrielatos, I.; Drakopoulos, V.; Neophytides, S.G. Carbon tolerant Ni-Au SOFC electrodes operating under internal steam reforming conditions. J. Catal. 2008, 259, 75-84.

32. Parizotto, N.V.; Rocha, K.O.; Damyanova, S.; Passos, F.B.; Zanchet, D.; Marques, C.M.P.; Bueno, J.M.C. Alumina-supported Ni catalysts modified with silver for the steam reforming of methane: Effect of Ag on the control of coke formation. Appl. Catal. A 2007, 330, 12-22.

33. Parizotto, N.V.; Fernandez, R.F.; Marques, C.M.P.; Bueno, J.M.C. Promoter effect of Ag and La on stability of Ni/A12O3 catalysts in reforming of methane processes. Stud. Surf. Sci. Catal. 2007, 167, 421-426.

34. Gavrielatos, I.; Montinaro, D.; Orfanidi, A.; Neophytides, S.G. Study of carbon deposition of Ag-doped Ni/YSZ electrodes under internal $\mathrm{CH}_{4}$ steam reforming conditions. Fuel Cell 2009, 9, 883-890.

35. Jeong, H.; Kang, M. Hydrogen production from butane steam reforming over Ni/Ag loaded $\mathrm{MgAl}_{2} \mathrm{O}_{4}$ catalyst. Appl. Catal. B 2010, 95, 446-455. 
36. Xu, Y.; Fan, C.; Zhu, Y.A.; Li, P.; Zhou, X.G.; Chen, D.; Yuan, W.K. Effect of Ag on the control of Ni-catalyzed carbon formation: A density functional theory study. Catal. Today 2012, 186, $54-62$.

37. Padeste, C.; Trimm, D.L.; Lamb, R.N. Characterization of $\mathrm{Sn}$ doped Ni/ $/ \mathrm{Al}_{2} \mathrm{O}_{3}$ steam reforming catalysts by XPS. Catal. Lett. 1993, 17, 333-339.

38. Nikolla, E.; Holewinski, A.; Schwank, J.; Linic, S. Controlling carbon surface chemistry by alloying: Carbon tolerant reforming catalyst. J. Am. Chem. Soc. 2006, 128, 11354-11355.

39. Nikolla, E.; Schwank, J.; Linic, S. Promotion of the long-term stability of reforming Ni catalysts by surface alloying. J. Catal. 2007, 250, 85-93.

40. Nikolla, E.; Schwank, J.; Linic, S. Comparative study of the kinetics of methane steam reforming on supported $\mathrm{Ni}$ and $\mathrm{Sn} / \mathrm{Ni}$ alloy catalysts: The impact of the formation of $\mathrm{Ni}$ alloy on chemistry. J. Catal. 2009, 263, 220-227.

41. Nikolla, E.; Schwank, J.; Linic, S. Hydrocarbon steam reforming on Ni alloys at solid oxide fuel cell operating conditions. Catal. Today 2008, 136, 243-248.

42. Penkova, A.; Bobadilla, L.; Ivanova, S.; Dominguez, M.I.; Romero-Sarria, F.; Roger, A.C.; Centeno, M.A.; Odriozola, J.A. Hydrogen production by methanol steam reforming on $\mathrm{NiSn} / \mathrm{MgO}-\mathrm{Al}_{2} \mathrm{O}_{3}$ catalysts: The role of $\mathrm{MgO}$ addition. Appl. Catal. A 2011, 392, 184-191.

43. Saadi, S.; Hinnemann, B.; Helveg, S.; Appel, C.C.; Abild-Pedersen, F.; Nørskov, J.K. First-principles investigations of the $\mathrm{Ni}_{3} \mathrm{Sn}$ alloy at steam reforming conditions. Surf. Sci. 2009, 603, 762-770.

44. Barcicki, J.; Denis, A.; Grzegorczyk, W.; Nazimek, D.; Borowiecki, T. Promotion of nickel catalysts for the steam reforming of methane. React. Kinet. Catal. Lett. 1976, 5, 471-478.

45. Rogatis, L.D.; Montini, T.; Lorenzut, B.; Fornasiero, P. $\mathrm{Ni}_{x} \mathrm{Cu}_{y} / \mathrm{Al}_{2} \mathrm{O}_{3}$ based catalysts for hydrogen production. Energy Environ. Sci. 2008, 1, 501-509.

46. Khzouz, M.; Wood, J.; Pollet, B.; Bujalski, W. Characterization and activity test of commercial $\mathrm{Ni} / \mathrm{Al}_{2} \mathrm{O}_{3}, \mathrm{Cu} / \mathrm{ZnO} / \mathrm{Al}_{2} \mathrm{O}_{3}$ and prepared $\mathrm{Ni}-\mathrm{Cu} / \mathrm{Al}_{2} \mathrm{O}_{3}$ catalysts for hydrogen production from methane and methanol fuels. Int. J. Hydrogen Energy 2013, 38, 1664-1675.

47. Chen, L.C.; Lin, S.D. The ethanol steam reforming over $\mathrm{Cu}-\mathrm{Ni} / \mathrm{SiO}_{2}$ catalysts: Effect of $\mathrm{Cu} / \mathrm{Ni}$ ratio. Appl. Catal. B 2011, 106, 639-649.

48. Djaidja, A.; Kiennemann, A.; Barama, A. Effect of Fe or $\mathrm{Cu}$ addition on $\mathrm{Ni} / \mathrm{Mg}-\mathrm{Al}$ and Ni/MgO catalysts in the steam-reforming of methane. Stud. Surf. Sci. Catal. 2006, 162, 945-952.

49. Zhang, J.G.; Wang, H.; Dalai, A.K. Development of stable bimetallic catalysts for carbon dioxide reforming of methane. J. Catal. 2007, 249, 300-310.

50. An, W.; Zeng, X.C.; Turner, C.H. First-principles study of methane dehydrogenation on a bimetallic $\mathrm{Cu} / \mathrm{Ni}(111)$ surface. J. Chem. Phys. 2009, 131, 174702:1-174702:11.

51. Resini, C.; Concepción, M.; Delgado, H.; Presto, S.; Alemany, L.J.; Riani, P.; Marazza, R.; Ramis, G.; Busca, G. Yttria-stabilized zirconia (YSZ) supported Ni-Co alloys (precursor of SOFC anodes) as catalysts for the steam reforming of ethanol. Int. J. Hydrogen Energy 2008, 33, 3728-3735.

52. Gonzalez-delaCruz, V.M.; Pereñiguez, R.; Ternero, F.; Holgado, J.P.; Caballero, A. In situ XAS study of synergic effects on $\mathrm{Ni}-\mathrm{Co} / \mathrm{ZrO}_{2}$ methane reforming catalysts. J. Phys. Chem. C 2012, $116,2919-2926$. 
53. Borowiecki, T.; Golebiowski, A. Influence of molybdenum and tungsten additives on the properties of nickel steam reforming catalysts. Catal. Lett. 1994, 25, 309-313.

54. Borowiecki, T.; Golebiowski, A.; Stasińska, B. Effects of small $\mathrm{MoO}_{3}$ additions on the properties of nickel catalysts for the steam reforming of hydrocarbons. Appl. Catal. A 1997, 153, 141-156.

55. Maluf, S.S.; Assaf, E.M. Ni catalysts with Mo promoter for methane steam reforming. Fuel 2009, $88,1547-1553$.

56. Abelló, S.; Bolshak, E.; Montané, D. Ni-Fe catalysts derived from hydrotalcite-like precursors for hydrogen production by ethanol steam reforming. Appl. Catal. A 2013, 450, 261-274.

57. Wang, W.; Su, C.; Ran, R.; Shao, Z.P. A new Gd-promoted nickel catalyst for methane conversion to syngas and as an anode functional layer in a solid oxide fuel cell. J. Power Sour. 2011, 196, 3855-3862.

58. Xu, J.; Chen, L.W.; Tan, K.F.; Borgna, A.; Saeys, M. Effect of boron on the stability of Ni catalysts during steam methane reforming. J. Catal. 2009, 261, 158-165.

(C) 2013 by the authors; licensee MDPI, Basel, Switzerland. This article is an open access article distributed under the terms and conditions of the Creative Commons Attribution license (http://creativecommons.org/licenses/by/3.0/). 